\title{
NIEUWE GEGEVENS OVER DE INBEZITNEMING VAN CURAÇAO OP DEN NIEUWJAARSDAG VAN 1807
}

\author{
DOOR
}

\section{B. DE GAAY FORTMAN}

Dit opstel laat zich het best lezen als een vervolg op dat over het bestuur van den gouverneur Changuion, eenige maanden geleden in dit tijdschrift verschenen ${ }^{1}$ ). De volkomen gelukte verrassing van Curaçao op den 1sten Januari 1807 door vier Engelsche fregatten onder den vice-admiraal Brisbane ${ }^{2}$ ) is het pakkend slot, dat past op de geschiedenis van een aantal jaren, waarin de bevolking - nog wel in/oorlogstijd - den gemeenschapsplicht niet had weten te stellen boven het eigenbelang, en ten slotte tot een toestand van lakschheid, onverschilligheid en zorgeloosheid was vervallen, die eindelijk ook het deel van den gouverneur was geworden. Toen Changuion nog maar een goed half jaar aan het bewind was, had hij met heengaan gedreigd, en eenige malen daarna vroeg hij den Raad der Amerikaansche Koloniën om verlof, wat hem geweigerd werd, en ten slotte zocht hij dan maar zijn rust door zich met zijn gezin terug te trekken op een buitenverblijf, een groote fout, die nauwelijks vergeeflijk lijkt in de omstandigheden, waaronder zij begaan werd.

Hoe slecht de burgerij haar plicht als gewapende macht nakwam, is duidelijk naar voren gekomen in het zooeven genoemde opstel. Later vond ik nog een sṕrekend bewijs van nalatigheid op ander gebied, dat der belastingheffing, waarbij ambtenaren en

$\left.{ }^{1}\right)$,Curaçao en onderhoorige eilanden Bonaire en Aruba van 1804 tot 1806 . Het bestuur van den gouverneur J. P. Changuion" D. W. I. G. 24ste jg., blz. 361 e.v., 25 ste jg. blz. 1 e.v.

$\left.{ }^{2}\right)$ Charles Brisbane 1769-1829, van 1808 tot 1829 gouverneur van St. Vincent.

Volgens een krantenbericht in Maart 1934 had de Engelsche vloot in dat jaar nog een schip „Curaçao", dat het wapen van Brisbane voerde. 
burgers samenspanden om aan de koloniale kas het deze toekomende te onthouden, ten einde er den eigen zak mee te spekken.

Mr. Bernardus Blok ${ }^{1}$ ) was 9 December 1806 op Curaçao aangekomen en had den 18den dier maand zijn ambt van fiskaal aanvaard. Langer dan tot 8 Januari 1807, toen hij den eed van trouw aan den Engelschen koning weigerde, heeft hij het niet uitgeoefend. Over zijn korte ervaring schreef hij 1 Juni 1807 van NewYork een brief aan den minister van Koloniën, waaraan het volgende is ontleend.

Vóór zijn ambtsaanvaarding had hij inlichtingen over de invordering van 's lands rechten gekregen, die op ernstige verwaarloozing wezen, en in het bijzonder gold dit van de heffing van inen uitgaande goederen. Niet de minste aandacht werd geschonken aan de aangiften, die daarvan gedaan werden, en dientengevolge geschiedden die zoo slordig, dat nauwelijks $1 / 4$ deel van de goederen, die in- en uitgevoerd werden, werd aangegeven. De visitateurs spanden samen met de kooplieden, en werden door hen zoo wèl beloond, dat zij rijk en brillant konden leven.

De secretaris Wenckebach ${ }^{2}$ ) vertelde hem, dat hij met eigen oogen gezien had, dat boven op het dek van een schip verscheiden balen katoen werden uitgevoerd, die niet op de uitklaring van den kapitein vermeld stonden, en hoewel Wenckebach dat gezegd had aan den persoon, die daartegen had te waken, was daaraan niets gedaan.

Blok was begonnen met den onderschout en de dienaren van justitie de noodige bevelen te geven en bij hen op trouwe plichtsbetrachting aan te dringen. Den visitateurs had hij te verstaan gegeven, dat hij hen doorzag, al kon hij hun nog niets bewijzen, en hen gewaarschuwd getrouw te zijn in de waarneming hunner posten.

Op het kantoor van den ontvanger De Veer ${ }^{3}$ ) had Blok tot zijn uiterste verbazing vernomen, dat de aangifte van goederen zonder behoorlijke specificatie geschiedde: lijnwaden werden als droge goederen aangegeven, de koopman gaf op wat hij wilde, en dat

1) D. W. I. G. 25sten jg. blz. 22.

$\left.{ }^{2}\right)$ Lodewijk George Wenckebach, geboren te Amsterdam, was sinds 1804 gouvernements-secretaris.

3) De gewezen commissaris Abraham de Veer (1767-1838) was in 1804 ontvanger-generaal geworden. Hij weigerde na 1 Jan. 1807 den eed aan den Engelschen koning, ging naar Holland, en was achtereenvolgens commandant-generaal ter kuste van Guinea, gouverneur der bovenwindsche eilanden en gouverneur van Suriname. 
waren dan goederen, waarvoor het minste recht verschuldigd was, en verzweeg die, waarop hoogere rechten vielen. De ontvanger kreeg nu van den fiskaal een schriftelijke order om geen lossing meer toe te staan dan na behoorlijke specificatie, wat ten gevolge had, dat toen gingans, chitsen, dimitten ${ }^{1}$ ), mousselines enz. aangegeven werden, wat tevoren niet geschied was, hoewel de pakhuizen en magazijnen, vooral der Amerikaansche kooplieden, overvloeiden. Het bleek, dat met twee aangiften ten behoeve van den lande bijna zooveel ontvangen was, als in de voorafgaande maand van 20 tot 25 schepen. Blok was dan ook tot de slotsom gekomen, dat, als voor de invordering van 's lands rechten behoorlijk zorg gedragen was, vrij wat meer in 's lands kas zou gestort zijn dan de 17 tot 20 duizend pesos van achten, die jaarlijks werden verantwoord.

Toen hij vernam, dat kapitein Luckett van den Amerikaanschen schoener ',Alert” bij zijn uitklaring o.a. cacao verzwegen had, liet hij dat schip aanhouden, en schikte de zaak voor 4000 dollars, de helft dadelijk en de wederhelft na zes maanden te betalen.

Tot zoover de mededeelingen van den fiscaal Blok. Het is haast ondenkbaar, dat Changuion van dit alles niets geweten heeft. Men mag aannemen, dat ten minste Wenckebach den gouverneur heeft ingelicht, zooals hij het later den fiskaal deed. Maar met Bloks voorganger mr. P. B. van Starckenborgh ${ }^{2}$ ), reeds in 1773 in de kolonie gekomen en aan tal van Curaçaosche families vermaagschapt, zal het kwalijk oproeien tegen den stroom van sleur geweest zijn. Ook later is het innen der belastingen een teer punt in het bestuursbeleid van Curaçao geweest.

P. A. Euwens O.P. noemt in zijn studie „Curaçao's eeuwfeest, 1816-4 Maart-1916" in De West-Ind is che Gids 1e jg. II, blz. 240-263 de hem bekende bronnen voor de beschrijving van ,,de inneming van Curaçao op Nieuwjaarsdag 1807", te weten: Ralfe's Naval Biography of Great-Britain dl. XX en stukken van Brisbane in de Royal St. Vincent Gazette van 1827, een en ander vertaald voorkomende in $\mathrm{De} \mathrm{Curaça} \mathrm{os} \mathrm{che} \mathrm{courant}$ van September en October 1833 nrs. 39-42, en daaruit overgenomen door M. D. Teenstra, De Nederlandsche West-Indische eilanden in derzelver tegenwoordigen toestand II, blz.'139-178, die ook

1) Gingang, gekleurde heelkatoenen stof; sits en diemet zijn katoenen weefsels, oorspronkelijk uit Voor-Indië afkomstig.

2) Zie D. W. I. G. 25sten jg., blz. 22. 


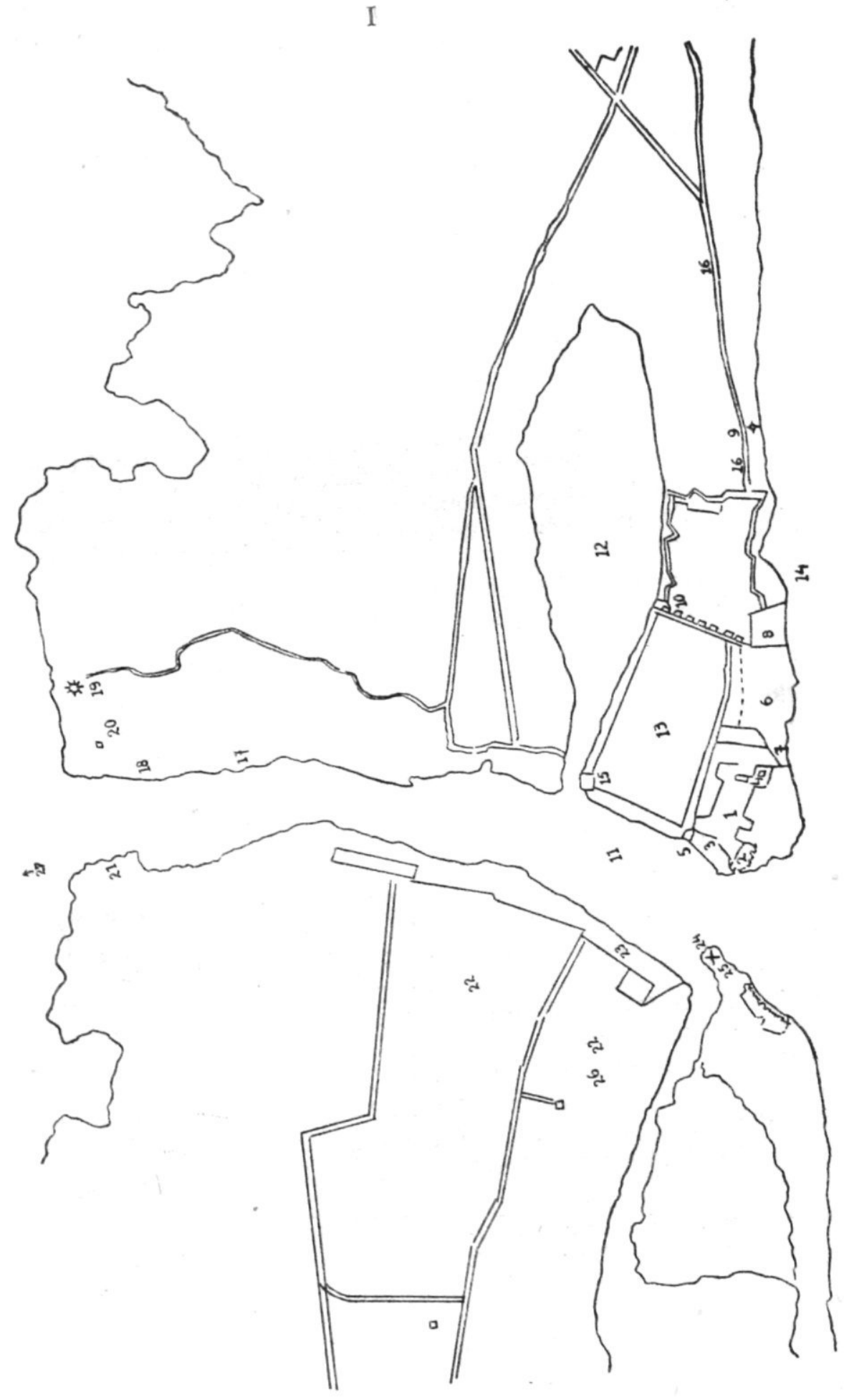




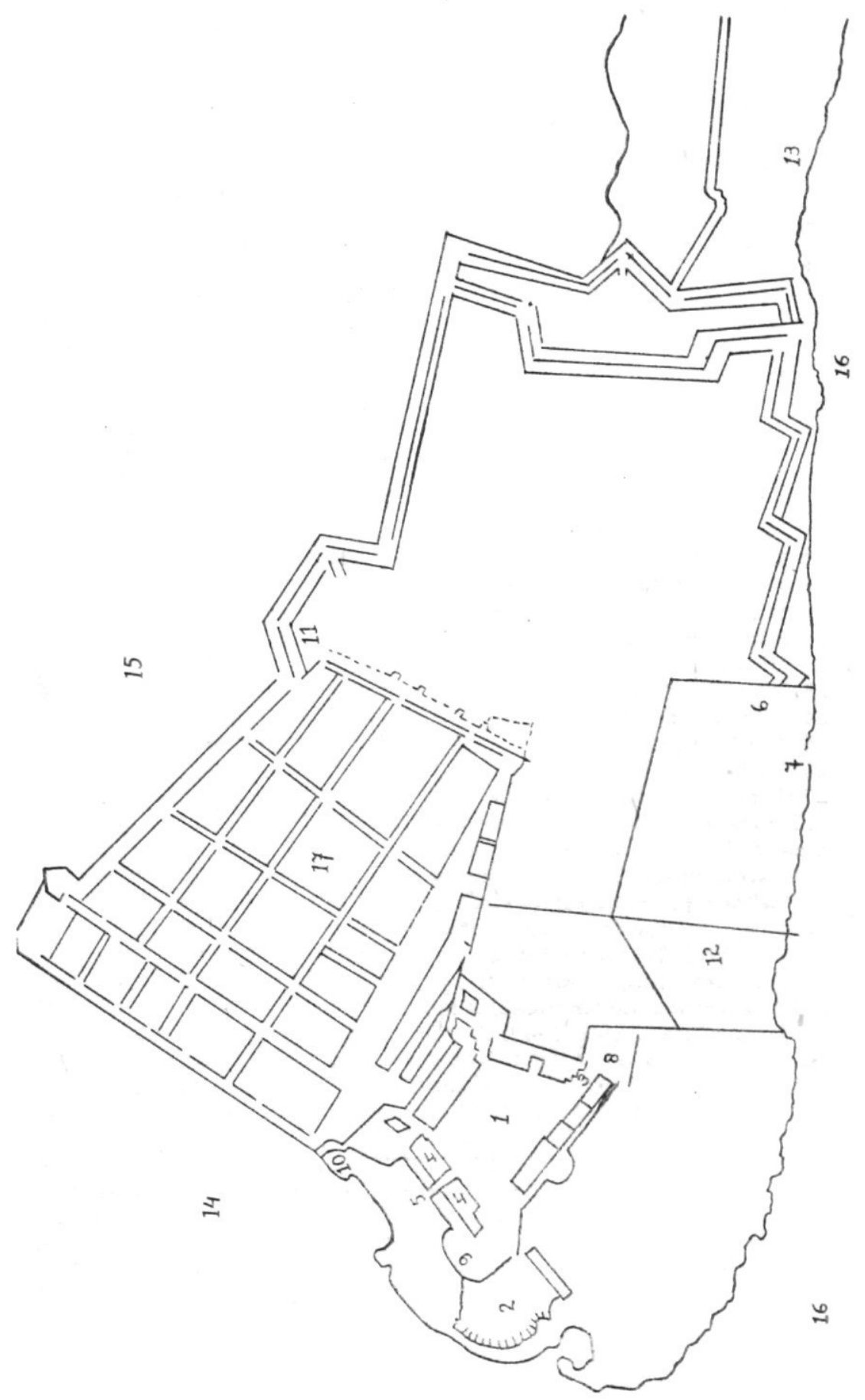


VERKLARING DER CIJFERS IN DE TEEKENINGEN, DIE VAN DE HAND van den heer C. K. Kesler te Amsterdam zijn:

\section{I}

1 Fort Amsterdam

2 Waterfort

3 Poort van het hoofdfort

4 Kruitmagazijn

5 Waagbatterij

6 Kerkhof

7 Batterij Halvemaen

8 Vlaggestok

9 Batterij Krommelijn

10 Bloedfort

11 St. Annabaai

12 Waaigat

13 Willemstad

14 Caraïbische zee

15 Huis van Primet?

16 Pietermaai

17 Klip Van der Meulen

18 Landsklip

19 Fort Republiek (Nassau)

20 Huis van M. Schotborgh?

21 Klip van Basden

22 Otrabanda (Overzijde)

23 Waterkant Otrabanda

24 Rifbatterij

25 Punto bravo

26 Cartagena

27 Richting naar Bleinheim

De op deze kaart niet voorkomende Cornetsbaai, Caracasbaai, Fort Beekenburgh, en Fuik, alles oostelijker dan dit kaartje strekt, alsmede de forten Waakzaamheid en Wreeker, ten westen van de St. Annabaai, vindt men op het kaartje tegenover bladz. 2 in de Januari-aflevering 1943.
II

1 Fort Amsterdam

2 Waterfort

3 Sortiepoortje

4 Gouvernementshuis

5 Poort van het hoofdfort

6 Vlaggestok

7 Kerkhof

8 Kruitmagazijn

9 Nieuwe batterij

10 Waagbatterij

11 Bloedfort

12 Batterij Halvemaen

13 Batterij de Krommelijn

14 St. Annabaai

15 Waaigat

16 Caraibische zee

17 Willemstad. 
aanhaalt De Curaça o s che courant van 9 Juli 1825 , waarin de onderwijzer Phoel zijn verhaal geeft naar de mededeelingen van tijdgenooten;

de Sententiën van de Hooge militaire vierschaar van Juli 1805 tot Maart 1809;

de Memorie aan Z.K.H. den Souvereinen Vorst der Nederlanden, overgegeven door en van wege Mr. P. J. Changuion, gewezen gouverneur des eilands Curaçao; ${ }^{1}$ )

rapport van den minister van Marine Verhuell aan koning Lode-

1) Deze gedrukte memorie van Changuion moet niet verward worden met een andere, geschreven, ,,Memorie van consideratien over Curaçao", door den gewezen gouverneur 20 Maart 1814 aan den koning gezonden (SS. 22 Juli $1814 \mathrm{nr}$. 72 Algemeen rijksarchief). Blijkens den begeleidenden brief stelde Changuion deze memorie op na afloop van het tegen hem aangespannen geding voor de Hooge militaire vierschaar De aanbieding aan den koning geschiedde na Changuions eerherstel, gevolgd door zijn benoeming tot griffier van de rechtbank te Goes. Het schrijven van de 465 bladzijden groote memorie was Changuion, zooals hij daarin schrijft, ,,een aangenaam tijdverdrijf in ledige uren". Met de aanbieding aan den koning wilde de schrijver dezen zijn hulde en dankbaarheid bewijzen, en tevens het vaderland en der kolonie nuttig zijn. Bijgevoegd is een kaart, ,'militair plan" van het eiland genaamd, met alle forten, batterijen, baaien en voornaamste bergen, van de hand van $\mathrm{P}$. Balfour van Burleigh, toen Changuions schoonzoon.

De memorie, in een inleiding en 12 hoofdstukken verdeeld, is een beschrijving van het Curaçao van Changuions tijd met aanwijzing van noodige en wenschelijke veranderingen. $\mathrm{Zij}$ is niet gericht op de verdediging van Changuions beleid gedurende zijn ambtstijd, en met name niet van zijn doen en laten van 22 tot 31 December 1807, al bevat zij meer dan één gegeven, dat ter beoordeeling van zijn bestuursbeleid van beteekenis kan zijn. Zoo wordt besproken het plan van verdediging van kapitein Schmidt, den commandant der artillerie, op Curaçao in Juni 1806 aan den gouverneur meegedeeld en door dezen doorgezonden aan den Raad der Amerikaansche koloniën (blz. 38); er is een kaart, waarop in teekening gebracht is de ,Linie van Defenzie des Eilands Curaçao zo als dezelve zig bevond den 1 Januarij 1807'" (tegenover blz. 114). Onder de bijlagen bevindt zich een plan, ook weer van luitenant Balfour, tot herovering van het eiland, en er is sprake van dergelijke plannen van Schmidt en D. Schuurman. Als terloops leest men de mededeeling, dat in de laatste maanden ongeveer $50 \%$ van de burgermacht afwezig was, zoodat, met een $\mathbf{5 0 0}$ man van het garnizoen, de geheele gewapende macht ongeveer 1200 man telde (blz. 60). Changuion heeft het ook over de expeditie naar Aruba in 1805, die in het geheel niet aan zijn verwachting beantwoord heeft, ,, hoe zeer men bij die gelegenheid ook zeer veele bravoure getoond hebbe". Ten slotte waren toen de Engelschen weggetrokken, en was de inbezitneming verder niet moeilijk (blz. 434). Ook leest men van het verzoekschrift van de Indianen op Bonaire (blz. 435; Zie D. W. I. G. 24ste jg., blz. 
wijk van 31 Juli 1807, inhoudende de verklaringen der zeeofficieren, die bij de verovering van het eiland op de Hollandsche oorlogsschepen in dienst waren (Algemeen rijksarchief. Marine 371 Rapporten van den maarschalk van Holland en minister der Marine aan Z.M. den Koning).

Het is niet waarschijnlijk, dat pater Euwens de sententiën en het rapport van Verhuell onder de oogen heeft gehad, omdat hij zijn opstel in Curaçao schreef, en hij deelt er dan ook niets uit mee, wat niet te vinden is in De Jonge, Geschiedenis van het Nederlandsche zeewezen (uitgave 1848, VI², blz. 613-625), en De Jonge zegt uitdrukkelijk, dat hij zijn verhaal ontleent aan deze bronnen en aan mededeelingen van den luitenant $\mathrm{H}$. W. de Quartel, destijds dienst doende aan boord van de „Kenau Hasselaar" ' $)$, die hem ook de nauwkeurigheid der verklaringen van de zeeofficieren in Verhuells rapport bevestigd heeft.

Het verhaal van Euwens nu is een critische samenvatting van deze bronnen, maar het verhaal zou in veel opzichten anders geworden zijn en de critiek veel ernstiger, als Euwens den inhoud gekend had van de portefeuille ,,Missives en bijlagen van Curaçao", die zich onder no. 179 bevindt in het archief van den Raad der Amerikaansche koloniën op het Algemeen rijksarchief te 's Gravenhage.

Daarin treft men o.a. aan de rapporten aan den gouverneur van alle bij deze zaak betrokken officieren der jagers en der artillerie, en Changuions mede daarop gegrond relaas, dat geen dagteekening draagt, maar na het verlaten der kolonie is geschreven; verder brieven van Changuion, op de thuisreis en na aankomst in Holland geschreven aan den minister van Koophandel en Koloniën, alsmede een uitvoerig verslag van den fiskaal Blok, dat van bijzondere waarde is, omdat hij als nieuweling onbevooroordeeld stond tegenover alles, wat hij meemaakte, en van het eerste alarm af in fort Amsterdam aanwezig is geweest.

Uit de sententiën van de Hooge militaire vierschaar is meer te halen, dan De Jonge, wien het alleen om de zeeofficieren te doen was, ervan vertelt, en de gedingstukken in deze zaken leveren

251 e.v.) en van Miranda's verblijf op Aruba (blz. 437; Zie D e I ndis che Gid s 1931, blz. 1-15).

De memorie aan den Souvereinen vorst, waarvan in den tekst sprake is, bevat enkele bijlagen, en het besluit van den Vorst, op deze memorie genomen, waarover later.

1) Zie D. W. I. G. 25sten jg., blz. 367. 
met name in het voorbereidend onderzoek van commissarissen der vierschaar nog meer dan één nieuwe verklaring op, ter beoordeeling van het geheel niet zonder beteekenis.

Het is mijn plan op deze nog ongebruikte bronnen een nieuw verhaal van het gebeurde op den nieuwjaarsdag van 1807 op te bouwen. Het geheel zal er niet fraaier op worden. Mijn critiek op de schets van Euwens zal in hoofdzaak zijn zegslieden treffen, ofschoon ook deze schrijver zelf wel eens blijkt lichtvaardig een gevolgtrekking gemaakt te hebben. Wat aan boord der Engelsche schepen heeft plaats gehad, met name vóór deze de haven binnenzeilden, ontsnapt aan contrôle van onze zijde.

Euwens' verhaal komt in het kort hierop neer.

Brisbane had het bevel over een eskader van 4 fregatten: de „Arethusa”, waar hij zelf aan boord was, de „Lathona”, de „Anson" en de „Fisgard”. Mede was aan boord Jan Bislick ${ }^{1}$ ), een Curaçaosche schipper. De commandant van de „Fisgard”, Bolton, deed 22 December 1806 den gouverneur een sommatie tot overgave van het eiland toekomen, die afgewezen werd.

Intusschen had naar aanleiding hiervan W. Schmidt ${ }^{2}$ ), de kapitein der artillerie, gesteund door den garnizoenscommandant F. H. Pfeiffer ${ }^{3}$ ), voorgesteld evenals vroeger de haven af te sluiten met een oud, log, koopvaardijschip, aan de oevers verbonden met aan weerszijden op palen rustende kettingen. Changuion achtte dit niet noodig. Zijn beroep daarvoor op Evertsz, den commandant der navale macht, is door De Quartel gewraakt.

Changuion belegde geen grooten krijgsraad, en ging den 31sten naar zijn buitenverblijf Bleinheim, niettegenstaande 's morgens nog een kleine Engelsche brik zich voor de haven had vertoond. De meeste zee- en landofficieren volgden des gouverneurs voorbeeld en gingen den avond doorbrengen bij Curaçaosche families, waar de feestvreugde in dien tijd tot den morgenstond en door

1) Zie D. W. I. G. 25sten jg., blz. 14.

2) T.a.p. 24ste jg., blz. 377.

s) Euwens noemt hem ten onrechte Pheiffer. Zie D. W. I. G. 25sten jg., blz. 4. Uit de mededeelingen van Pfeiffer aan commissarissen der Hooge militaire vierschaar kan nog worden ontleend, dat hij opgaf „,circa 34 Jaaren" oud te zijn en gediend te hebben eerst als cadet bij de artillerie, in 1791 was hij officier geworden in het regiment van Doff, in 1795 had hij ontslag genomen, in 1799 was hij luitenant-adjudant geworden bij de gewapende burgermacht in Oosterhout, in 1802 1ste luitenant bij het 8ste bataljon jagers en in 1803 op Curaçao tot kapitein bevorderd. 
het minder volk ook nog den geheelen nieuwjaarsdag werd doorgezet.

Van deze luidruchtige feestvoering was Brisbane, misschien door verraad, op de hoogte en daarvan wilde hij gebruik maken ${ }^{1}$ ).

De Engelsche schepen, den oosthoek van het eiland omgezeild zijnde, lieten zich, begunstigd door wind en stroom, rustig langs het eiland afzakken, doch werden om kwart voor vijven in den morgen op oostseinpost en Fuik opgemerkt. De alarmschoten, die de commandant van fort Beekenburgh gaf, werden overstemd door de muziek op de danspartijen, het gebons van den tamboer, het luidruchtig geschreeuw der slavenbevolking en het oorverdoovend geraas van het vuurwerk, zoodat men in de stad niets opmerkte.

Voorbij de Krommelijn heschen de fregatten de Hollandsche vlag, en het was bijna 6 uur, toen zij zonder eenigen tegenstand te ontmoeten, de „Arethusa” voorop, de haven binnenzeilden. ,'Geen enkele officier noch van de land- noch van de zeemacht was op zijn post".

Euwens vermeldt dan de twee omstandigheden, waaraan De Jonge het ongehinderd kunnen binnenzeilen van de haven toeschrijft: het oudejaarsnachtfeest, omdat daardoor de batterijen en forten slecht bezet waren en er weinig of geen wacht gehouden werd, zoodat de vijandelijke schepen eerst zeer laat ontdekt werden, en het gebruik door de Engelsche schepen van de Hollandsche vlag, die in West-Indië, met name te Curaçao, als parlementaire vlag gold, waardoor zij, die bij de batterijen en op de forten waren in twijfel geraakten over het oogmerk der Engelschen, en eerst toen het te laat was, bemerkten, dat zij misleid

1) Teenstra (II, 130) schijnt den Engelschen zeer kwalijk te nemen, dat zij voor hun aanval den dag kozen na een avond en nacht, die men gewoon was ,,lustig te vieren, zoo door het afsteken van vuurwerken, als het gebruiken van geestrijke vochten" en de bezetting met haar officieren zich te buiten gegaan was aan ,een overvloedig gebruik van wijn, grog en dergelijke hartversterkingen". Hij vergelijkt dit niet alleen met het hernemen van Porto bello door de Spanjaarden op een Zondagmorgen, toen de troepen van Macgregor zich den avond te voren door geestrijke dranken tot verdediging onbekwaam hadden gemaakt, maar ook met de herovering van de „Hermione” door den Engelschen kapitein Hamilton, die daartoe het oogenblik koos, waarop de Spaansche wacht den rozenkrans bad, en hij stelt het op één lijn met de pogingen der Russische veldtochten om de Turken in het gevecht te wikkelen op het einde der groote vasten, als deze door langdurige onthouding verzwakt waren, en met het kiezen van den Sabbath om den Joden aan te vallen. 
waren. Euwens meent, dat deze redeneering niet opgaat, omdat de officieren niet op hun post waren, en dus die vlaggen niet opgemerkt hebben.

De „,Kenau Hasselaar” lag met den achtersteven tegenover de batterij de Waag en de ,Suriname” even voorbij het Waaigat.

De gouverneur was naar buiten. Evertsz, Van Nes ${ }^{1}$ ) en De Quartel waren naar een feestpartij. Op het hooren van twee alarmschoten van het Waterfort ijlden zij naar boord, waar de manschappen, op de ,Kenau Hasselaar” onder bevel van kapiteinluitenant Slotendijck ${ }^{2}$ ), ter verdediging gereed stonden.

Toen de „Arethusa", gevolgd door de andere schepen, binnenzeilde, gaven de beide Hollandsche schepen vuur, maar de „Arethusa" beantwoordde het vuur niet, zeilde de „Kenau Hasselaar” voorbij, ging vlak vóór het Waaigat liggen en opende zijn batterijen op het fort Republiek. De „Latona”, die bij het binnenvaren de laag van de „,Kenau Hasselaar” kreeg, ging tegenover de Breestraat liggen en vuurde op de „Kenau Hasselaar”, waarbij Evertsz sneuvelde. Het derde Engelsche schip, de „Anson”, nam voorbij de ,Suriname” ligplaats bij de werf en teisterde dit schip zoo, dat de meeste leden der bemanning, bijna geheel uit kleurlingen bestaande, over boord sprongen en kapitein Van Nes en luitenant Moqué $\left.{ }^{1}\right)$ gekwetst werden. De kapitein van de „Anson”, Lydiard, haalde zelf de vlag van de „Suriname” neer. De „Fisgard", het vierde Engelsche fregat, nam post vóór het fort Amsterdam en opende het vuur daarop en op de „Kenau Hasselaar”; ook daar sprong de bemanning over boord, het schip werd geenterd en de vlag neergehaald.

Dat is het verhaal van de zeeofficieren, zegt Euwens, maar Phoel vertelt het anders. Volgens dezen was Evertsz nog op een bal, toen de Engelsche schepen reeds binnen waren en werd hij bij het aan boord gaan gedood door Engelsche schrootschoten ter beantwoording van het vuur, dat de wachthebbende luitenant De Veer ${ }^{4}$ ) op de „Kenau Hasselaar” had laten geven. Een Engelsch officier van de „Arethusa" vertelt, dat er van de Hollandsche schepen eerst gevuurd is, toen de „Arethusa" rustig voor het

1) Over hem D. W. I. G. 24sten jg., blz. 367

2) J. Slotendijck was in 1786 lieutenant bij de admiraliteit van Friesland geworden en had nu den rang van majoor. In den regel wordt hij Sloterdijk genoemd, zelf teekent hij Slotendijck.

3) D. W. I. G. 25sten jg., blz. 19.

“) ,, Jonker de Veer" t.a.p. blz. 2. I. de Veer wordt als cadet supernumerair en als luitenant-titulair aangeduid. 
Waaigat lag, en Brisbane heeft medegedeeld, dat hijzelf de vlag van de „Kenau Hasselaar” heeft neergehaald, nadat De Veer dat geweigerd had.

Van het fort Amsterdam was nog altijd geen schot gelost. Daar had de wachthebbende officier Siecker ${ }^{1}$ ), toen de Engelsche schepen binnenzeilden den garnizoenscommandant Pfeiffer doen waarschuwen, maar die was eerst in den morgenstond, zwaar geladen, van een feestpartij thuis gekomen, viel weer in slaap, en toen hij op de tweede boodschap tot bezinning kwam, zag hij de Engelschen reeds op de muren van het fort Amsterdam.

Met stormladders hadden zij, Brisbane voorop, de muren beklommen, toen 200 man daar zich gereed maakten weerstand te bieden. Pfeiffer werd met den blooten degen in de hand bij een der schietgaten gearresteerd door Brisbane. Slechts één negersoldaat bood tegenstand en schoot zijn geweer af op den Engelschen opperbevelhebber.

Eenige officieren en manschappen waren van fort Amsterdam naar fort Republiek gevlucht. Van daar begon men toen op de Engelsche schepen te vuren, waardoor eenigen werden gekwetst en gedood.

Changuion was op Bleinheim achter het Schottegat en werd daar opgeschrikt door de kanonschoten in de haven; met vrouw en kinderen stapte hij in een tentbootje en, misleid door de Hollandsche vlag op fort Amsterdam, liet hij zich daarheen roeien, waarmee een uurtje gemoeid was. Hij stapte aan wal tusschen de werf van den heer Van der Meulen ${ }^{2}$ ) en die van den heer Foulke, vóór het woonhuis van den heer M. Schotborgh, en ging over het Waaigat naar de stad. Aan de poort van het hoofdfort werd hij door den Engelschen schildwacht waarschijnlijk niet herkend en afgewezen, waarna hij aan de oostzijde door het sortiepoortje het fort binnenkwam, onmiddellijk gevangen genomen werd en naar

1) Johan Frederick Siecker, in 1766 of 1767 geboren te Lubbecke, had 2 jaar op zee en 18 jaar bij de Oost-Indische compagnie aan de Kaap de goede hoop gediend. Als Engelsch krijgsgevangene was hij op Barbados gebracht en in 1804 gelost. Sedert dien deed hij dienst bij de 2de cie. 8ste bat. jagers op Curaçao. Hij behoorde dus tot de zoogenaamde „Caapsche officieren”. Euwens noemt hem Sickesz.

2) De werf of klip van Van der Meulen, waarbij ook het woonhuis van $M$. Schotborgh stond, lag op den oostelijken oever van de SintAnnabaai, bezuiden fort Republiek, met de ,Landsklip" tusschen werf en fort. Aldus wijst uit een ruwe teekening bij een verhoor van Changuion door commissarissen der vierschaar. 
de groote zaal gebracht,waar mevrouw Changuion een bezwijming nabij was.

Mr. P. B. van Starkenborgh ${ }^{1}$ ) werd in een roeibootje, terwijl hij de haven overstak, gevangen genomen, en ook in de zaal van het gouvernementshuis gebracht.

Daar eischte Brisbane de onmiddellijke overgave en Changuion moest een officier met een Engelschen officier naar fort Republiek zenden met bevel terstond met schieten op te houden. Brisbane dreigde daarbij anders het fort met 1200 man te bestormen.

Op verzoek van Changuion stond Brisbane eenige minuten een raadsvergadering toe, waar tot capitulatie besloten werd, en de gouverneur wist te bedingen, dat de burgers hun eigendommen zouden behouden. Het aanbod om civiel gouverneur te blijven wees Changuion van de hand.

Van fort Republiek, zegt Euwens, was Balfour van Burleigh commandant, die onmiddellijk voldeed aan Changuions bevel om het schieten te staken. Daar Balfour een schoonzoon van den gouverneur was, heeft men hierin grond gevonden voor een beschuldiging van verraad aan Changuions adres. Euwens acht het bewijs daarvan niet geleverd ${ }^{2}$ ).

Het garnizoen en de bemanningen, een 300 man, werden met den gouverneur en de officieren op de „Anson" naar Jamaica gevoerd, waar zij 10 Januari aankwamen, en naar Holland gezonden werden, nadat zij hun eerewoord hadden gegeven, niet meer de wapenen tegen Engeland te zullen voeren.

9 Juni in 's Gravenhage aangekomen, werden Changuion, Pfeiffer, Van Nes en Slotendijck 12 Augustus gevangen gezet. 21 Maart 1808 werden de eerste twee tot de straf met den kogel veroordeeld, en de zeeofficieren vrijgesproken. Changuion kreeg van koning Lodewijk Napoleon kwijtschelding van straf en Pfeiffer lijfsgenade. Van Willem I verwierf Changuion in 1814 abolitie.

Dit is in het kort het verhaal, dat Euwens uit de genoemde bronnen heeft samengesteld. Het zal hierna blijken, dat hiervan, vooral wat de bijzonderheden betreft, niet veel overblijft. Met name wat deze schrijver aan Phoels tijdgenooten ontleent, is weinig meer dan fantasie. Voor de zooveelste maal wordt het be-

$\left.{ }^{1}\right)$ Ten onrechte noemt Euwens hem nog raad-fiskaal. In die hoedanigheid was hij opgevolgd door mr. B. Blok, en zelf was hij vice-president van den Raad van justitie geworden.

$\left.{ }^{2}\right)$ Over P. Balfour van Burleigh zie D. W. I. G. 25sten jg., blz. 15, waar men ook vindt meegedeeld, dat hij eerst ruim twee jaar later een dochter van Changuion huwde. 
wijs geleverd, dat de geschiedenis van Curaçao, uit de bronnen bestudeerd, een geheel ander beeld geeft, dan de plaatselijke geschiedschrijvers geteekend hebben.

Wat van Engelsche zijden over de inneming geschreven is, kan verwaarloosd worden. Voor een groot deel betreft het de vraag, of de eer van het plan en de eer der overwinning toekomt aan Brisbane of aan Wood ${ }^{1}$ ), den commandant van de ,Latona”. Merkwaardig daarbij is de voorstelling, dat het derde Engelsche fregat ,Anson" eerst een half uur na de ,Arethusa” en „Latona” zou zijn binnengezeild, en de „Fisgard” weer vijf kwartier later, zulks in strijd met het eenparig getuigenis van Hollandsche zijden.

Een verslag van de gebeurtenissen, die geleid hebben tot de verovering van Curaçao op 1 Januari 1807, moet inderdaad beginnen bij de sommatie, die kapitein Bolton van de „Fisgard” den gouverneur den 22sten December 1806 deed toekomen. Daarover is reeds een en ander meegedeeld uit het journaal van den gouverneur ${ }^{2}$ ).

In zijn brieven is Changuion daarover uitvoeriger en ook de fiskaal Blok vertelt er iets van in zijn verslag.

Changuion, Blok, Evertsz, Slotendijck, Pfeiffer en anderen waren op een maaltijd bij Van Starckenborgh, die aan de Overzijde van de haven (Otrabanda) op Cartagena woonde. Blok vertelt, dat op het gezicht van vier vijandelijke schepen, die de haven naderden, Evertsz opstond met de woorden: ,wat d...., zij willen de haven inzeilen; ik ga na boord van mijn schip, want ik wil aldaar liever doodgeschoten worden, dan hier te blijven zitten", en heen ging. Pfeiffer bleef zitten en deed niets. Changuion, die in zijn relaas spreekt van 1 fregat en 2 brigantijnen, waarvan een tweetal de parlementaire vlag heesch, zegt, dat hij Evertsz last gaf om naar zijn boord te gaan, het sein te beantwoorden en twee gewapende sloepen de van het fregat uitgezette sloepen tegemoet te doen gaan, den Engelschen officier aan boord van de „Kenau Hasselaar" te brengen en de depêches aan hem, Changuion te doen bezorgen. Een uur later kwam luitenant De Quartel die

1) James Athol Wood 1756-1829, vice-admiraal.

$\left.{ }^{2}\right)$ D. W. I. G. 25sten jg., blz. 25 en 26.

s) Euwens t.a.p. blz. 246. 
brengen. Wat de inhoud was vernam Blok eerst later van particuliere personen. Boltons verwijt, dat de gouverneur de sommatie niet ter kennis van den raad heeft gebracht, is dus feitelijk juist, want anders moest Blok, die als fiskaal daarin zitting had, daarvan officieel vernomen hebben.

Changuion deelt mee, dat hij zonder aarzeling op de uitnoodiging om zich onder de protectie van den koning van Engeland te begeven ${ }^{1}$ ) geantwoord heeft:

„Ik verklaare, dat wij op den 16den Eed van getrouwheid aan den Koning van Holland gedaan hebbende, zeer zekerlijk op den 22en ook in het vervolg niet meineedig worden zoude, en wat er ingevolge de gedaane bedreigingen ook gebeuren mogt ons als Eerlijke Lieden zouden poogen te gedraagen!'” ${ }^{2}$ )

Dit antwoord gaf de gouverneur nog bij Van Starckenborgh, en daar had ,,aan een der vensters" de bespreking plaats tusschen Schmidt, Pfeiffer, Evertsz en den gouverneur. Besloten werd, dat Schmidt de batterijen ook 's nachts zou doen bezetten. Over de sluiting van de haven was men ongerust, want eenige maanden tevoren was de oude hoeker ,Marianne” weggenomen, daar zij vergaan was en anders zou gezonken zijn. Schmidt stelde voor de „Suriname” en de „Kenau Hasselaar" aan den mond van de haven te leggen, en vond gehoor bij Changuion en Pfeiffer, maar Evertsz was ertegen, omdat de schepen dan voor de batterij de Waag in den weg zouden liggen of zelf aan het vuur van deze zouden zijn blootgesteld. Hij zegde toe bij een aanval de schepen eenige vademen naar voren te zullen brengen, neus aan neus, en dan zou het vuur van de schepen en van de batterijen den Engelschen wel zooveel eerbied inboezemen, dat hun de lust spoedig zou vergaan om binnen te komen of te trachten de haven te forceeren.

Tot zoover het journaal, dat met geen woord rept van het sluiten van de haven met den havenketting. Changuion roert die zaak aan in zijn memorie (blz. 13), maar zegt daar volstrekt niet, dat zij toen ter sprake is gekomen. Hij deelt alleen als feit mee, dat die ketting reeds vóór zijn komst op het eiland vergaan was $\left.{ }^{3}\right)$. Pfeiffer,

1) Zoo omschrijft Changuion den inhoud der sommatie. Deze is niet bewaard gebleven, en het valt dus ook niet te zeggen, of juist is wat Changuion later beweerd heeft, dat hem daarin aangeboden werd gouverneur te blijven.

2) Zie ook Changuions Memorie blz. 12.

s) Ook al zou de ketting wel bruikbaar geweest zijn, dan nog was voor het sluiten van de haven daarmee nog heel wat meer noodig, dat 
die volgens Euwens een voorstel van Schmidt tot sluiting van de haven met den ketting zou gesteund hebben, herinnerde zich later voor commissarissen van de Hooge militaire vierschaar de zaak niet meer goed. Hij vertelde daar, dat hij, toen 's avonds de schepen voor de haven bleven kruisen, den gouverneur had voorgesteld de haven te sluiten, zonder te vermelden op welke wijze hij dat had willen doen. De gouverneur vroeg advies aan Evertsz, die, voor zoover Pfeiffer zich herinnert, antwoordde, dat het niet noodig was. Het is in ieder geval zeer onwaarschijnlijk, dat, zooals De Quartel aan De Jonge (blz. 617) meedeelde, Evertsz herhaaldelijk zonder gevolg bij den gouverneur op het herstel van de hulk en het spannen van den ketting zou hebben aangedrongen, en dat de gouverneur over een desbetreffend voorstel van Schmidt een grooten krijgsraad had moeten beleggen, heb ik niet, zooals De Jonge, in de sententie van de vierschaar gelezen. Schmidt zelf beweert ook niet, dat hij heeft voorgesteld de haven met een ketting te sluiten. De Veer, de gewezen commissaris, en R. 't Hoen, de vendumeester, zijn o.a. over dezen ketting door commissarissen van de vierschaar gehoord; eerstgenoemde deelde toen mee, dat de ketting, omdat hij geheel vergaan was, door den hoeker was vervangen, naar hij meent in Februari 1804, dus toen hijzelf nog met Berch de directie voerde, en 't Hoen wist zich van den ketting niets te herinneren.

Heeft Changuion naar aanleiding van de sommatie nog bepaalde bevelen gegeven, orders uitgevaardigd? In zijn relaas zegt de gouverneur dat met zooveel woorden en voor de vierschaar heeft hij het uitdrukkelijk volgehouden en gesproken van "striktste" orders tot waakzaamheid, vooral des nachts, tot voortdurend uitkijk houden en het bezetten van de hoofdfortres, door hem gegeven, alsook van verschillende maatregelen, door hem bevolen voor het geval van verschijning van vijandelijke schepen en bij den minsten schijn van attaque, o.a. over het doen der alarmschoten. Hij voegt er aan toe, dat dit alles bovendien vanzelf zou hebben gesproken. Binnen een half uur na het eerste alarmschot ${ }^{1}$ )

niet ineens in orde te brengen was. Dat bleek, toen in 1831 weer overgegaan is tot de sluiting van de haven op deze wijze, en dit heel wat voeten in de aarde heeft gehad. Zie gouvernements-journaal van Rammelman Elsevier sr. 1831, 1832.

1) Pfeiffer verklaarde voor commissarissen der vierschaar, dat van alarmschoten gold, dat, wanneer er 4 gelost waren, de artillerie zich over de batterij moest verdeelen, garnizoen en burgerwacht onder de wapenen moesten komen. 
zouden de batterijen bezet hebben kunnen zijn in den omtrek van de hoofdfortres, terwijl bij de heldere maan de vijand zeker op een uur afstand te zien zou zijn. Het was niet noodig en zou de manschappen maar afgemat hebben, als de batterijen voortdurend bezet waren geweest.

Pfeiffer heeft tegenover commissarissen het bestaan van deze orders en het bevelen van bepaalde maatregelen van den gouverneur naar aanleiding van de sommatie van 22 December 1806 steeds ontkend ${ }^{1}$ ). Schmidt, die met den commandant den gouverneur thuis bracht van den maaltijd bij Van Starckenborgh, heeft verklaard, dat Changuion gezegd heeft : „Heeren, wij dienen vannacht op te passen en actief te zijn".

$\mathrm{Na}$ het overbrengen der sommatie had de „Fisgard” met de brikken afgehouden naar de zuid. Den volgenden dag waren zij nog kruisende gezien, maar den 24sten was het fregat en den 25sten waren de brigantijnen uit het gezicht verdwenen. Dien laatsten dag sprak Changuion nog met een kapitein, die onder Aruba was geweest en verklaarde, dat hij geen vijandelijke schepen gezien had. De gouverneur nam toen aan, zooals hij zelf zegt, dat de sommatie verder zonder gevolg zou blijven.

Uitvoerig is reeds meegedeeld ${ }^{2}$ ) wat volgens het journaal op 31 December 1806, toen 's morgens weer een vijandelijke brik geseind was, tusschen gouverneur en garnizoenscommandant zou besproken zijn. Reeds 3 September 1806 had Louis Schlemm ${ }^{3}$ ) als gemachtigde van den oud-gouverneur Lauffer aan mevrouw Changuion het landhuis op Bleyn (Blenheim of Bleinheim) ten gebruike door de familie aangeboden en op aanraden van den chirurgijn-majoor der jagers Pieter Maes, die in dien tijd den gouverneur had aangeraden zich zooveel mogelijk van zijn drukke werkzaamheden te ontdoen, was van dit aanbod gebruik gemaakt. Blok had bij zijn aankomst daar zijn opwachting gemaakt bij den gouverneur, die daarna in de stad was teruggekeerd. Daarheen zou de familie nu weer gaan.

Voor commissarissen van de vierschaar heeft Pfeiffer verklaard,

1) In het archief van den Amerikaanschen raad bevindt zich onder no. 179 een register van de orders, door Pfeiffer als garnizoenscommandant van den gouverneur ontvangen; het loopt echter niet verder dan tot 31 Dec. 1805.

$\left.{ }^{2}\right)$ D. W. I. G. 25sten jg., blz. 26 en 27.

3) Over dezen Schlemm t.a.p. blz. 8. Het briefje van 3 Sept. 1806 ligt in het dossier der Hooge militaire vierschaar, waar ook te vinden is een notarieele verklaring van 27 Jan. 1808 van Maes, waaraan het hierboven meegedeelde ontleend is. 
dat hij zich niet herinnerde den gouverneur aangespoord te hebben om ,,gerust" naar buiten te gaan, maar de mogelijkheid toegegeven, dat dit zoo kan zijn. Verder zei hij, dat de gouverneur hem niet verzocht had niet naar de partij bij den ontvanger De Veer op Mundo Nobo te gaan, maar dat hij eigener beweging te kennen gegeven had van de uitnoodiging daartoe geen gebruik te zullen maken. Changuion heeft er veel waarde aan gehecht, dat de vierschaar van de juistheid zijner voorstelling overtuigd zou zijn, en daartoe verzocht, dat mevrouw Changuion zou worden gehoord. Dat verhoor heeft ook door commissarissen plaatsgevonden, en mevrouw Changuion heeft toen verklaard, dat na zijn bezoek aan den gouverneur Pfeiffer bij haar was gekomen, koffie had gedronken, haar van de Engelsche brik gezegd had: ,,dat is niets, hij steekt de Zuyd op" en den inmiddels binnengekomen gouverneur gerust gesteld had, dat hij wel naar buiten kon gaan, en gezegd, dat hij niet uit het fort en niet op de partij zou gaan.

Tusschen 4 en 5 uur ging de gouverneur dien 31sten December 1806 met mevrouw, twee dochters en een zoontje naar Bleyn, gelegen aan het noordelijk gedeelte van het Schottegat, achter den westelijken oever van de St. Annabaai. Het was zijn bedoeling op deze wijze te ontkomen aan de nieuwjaarsfestiviteiten, waarbij, zooals mevrouw Changuion aan Pfeiffer gezegd had, de officieren gewoon waren meer te drinken, dan goed voor hen was.

Het commando had de gouverneur niet overgegeven, ,als zijnde", zooals Blok uit zijn onderhoud met Changuion op den morgen van den oudejaarsdag verslag doet, ,, door Hem de nodige orders gesteld en gegeven, dat alle zaaken ter zyner kennisse gebracht en door Hem zelve afgedaan zouden worden". Voor zich zelf had de gouverneur de berekening gemaakt, dat schepen op een afstand van één uur, vóór zij bij de haven konden zijn, verkend konden worden, en hij, dadelijk gewaarschuwd, zeker binnen een half uur op het gouvernementshuis zou kunnen zijn en dus nog alle noodige maatregelen zou kunnen nemen. Het afgesproken sein, dat den gouverneur binnen de hoofdfortres moest terugroepen, was: 1 schot van fort Amsterdam, beantwoord door 2 schoten van fort Republiek en dààr de Hollandsche vlag omgekeerd geheschen.

Deze berekening was wel heel kinderlijk. Op welken afstand schepen te zien zouden zijn was natuurlijk reeds bij dag afhankelijk van het uitzicht en er was in het verleden allerminst grond te vinden voor de veronderstelling, dat een aanval juist op de haven in de bedoeling zou liggen. 
Over den duur van de reis van Bleyn naar Willemstad is in het geding veel te doen geweest, en commissarissen hebben dit punt zeer nauwkeurig onderzocht, doch zeer uiteenloopende antwoorden gekregen. De gouverneur heeft erop gewezen, dat hij 4 beste pagaaiers tot zijn beschikking had en rekende met deze, als zij wat zouden doorzetten, den tocht in 16 à 20 minuten te kunnen doen. Met 2 pagaaiers had hij 't in 1 uur tijds wel gedaan en Schlemm had indertijd ook van een half uur afstands gesproken. Euwens (blz. 259) schat den duur op ,,een goed uurtje”. Van den luitenant Rabainne ${ }^{1}$ ) is een notarieele verklaring, die 25 minuten opgeeft, luitenant Balfour spreekt van een klein half uur, het raadslid 't Hoen ${ }^{2}$ ) geeft aan commissarissen op drie kwartier en De Veer zelfs $1^{1} / 2$ uur door de voortdurende oostelijke en noordoostelijke winden.

Volgen wij de Engelsche schepen, nadat zij bij Oostpunt aan de zuidelijke kust van Curaçao gekomen waren.

Op fort Beekenburgh aan de Caracasbaai voerde het commando de 2 de luitenant der artillerie C. Hendriks ${ }^{3}$ ). Deze deelt mee, dat in den morgen van 1 Januari 1807 om kwart voor vijven ${ }^{4}$ ) een fregat onder het bereik van het geschut van den uitkijk kwam, waarop hij een scherp 18-ponder-schot deed. Kort daarop zag hij een tweede, derde en vierde fregat, komende alle voor den wind af, waarop hij, ofschoon de schepen buiten het bereik van zijn geschut waren, nog twee scherpe schoten met een 18-ponder had gedaan ,,met de waaragtige intentie, om door de klank der schoten, die voor de wind af in 't hoofdfortres konden gehoord worden, de bezetting te adverteeren van overal uit te zien en zig klaar te maken".

Blok heeft 6 Juni 1807 een brief ter aanbeveling van luitenant Hendriks aan den minister van Koloniën geschreven. Daarin deelt hij mee, dat Brisbane op Zondag 12 Januari 1807 in tegen-

1) D. W. I. G. 24sten jg., blz. 374

$\left.{ }^{2}\right)$ Reinier 't Hoen, geboren ongeveer 1765 te Utrecht, komt in 1802 als vendumeester voor en was raadslid sinds 1804 .

3) Cornelis Hendriks, geboren te Utrecht in 1782 of 1783, had 28 maanden gediend als cadet op 's lands schip van oorlog „, Oldenbarneveld" en bij het 5de bataljon artillerie. Sinds 1802 was hij daarbij 2de luitenant.

-) De eenige, die een vroeger tijdstip noemt, is de luitenant Rabainne in zijn notarieele verklaring. Hij had om half vijf de eerste schoten van Caracasbaai gehoord, en een half uur of drie kwartier later waren deze herhaald. 
woordigheid van Changuion, Wenckebach en Slotendijck aan hem had verklaard, dat de luitenant Hendriks een zeer attent officier was, want dat hij door de schoten van het fort Beekenburgh genoodzaakt was geweest meer zeilen bij te zetten, ten einde met den meest mogelijken spoed de haven te bereiken uit vrees, dat anders zijn toeleg zou mislukken.

Omtrent den afstand van Caracasbaai naar de haven is bij het onderzoek niet anders naar voren gekomen, dan dat deze één groot uur gaans is. Op dezen weg moesten de schepen de Cornetsbaai en de batterij Krommelijn voorbijvaren als de eenige plaatsen, waar gevaar kon dreigen. Er was een instructie van 5 November 1804, volgens welke iederen nacht een piquet moest uitgaan van de hoofdfortres naar Cornetsbaai en den geheelen nacht door op verschillende plaatsen uitkijk houden. Schmidt heeft verklaard, dat dit den 31sten December 1806 ook gebeurd is, maar hoe zou hij, die met ziekteverlof was, dit nu juist weten. Er wordt verder in de stukken over dit piquet ook niet gesproken.

Van de Krommelijn ontbreekt een rapport. Voor de bewering, dat deze batterij niet bezet zou zijn geweest bestaat geen grond. Door commissarissen van de vierschaar is als getuige gehoord de 50-jarige bombardier Johan Gotlob Henning, die deze batterij commandeerde. Hij verklaarde, dat hij om 4 uur een schip gezien had en om half vijf twee schepen, waarop hij telkens rapport aan de hoofdwacht had laten doen. Om kwart voor vijven zag hij 4 schepen, alle nog ter hoogte van Caracasbaai, vanwaar hij tegelijkertijd drie schoten hoorde, en ook hiervan had hij door een kanonnier bericht naar de hoofdwacht gezonden. Toen het seinschot en de alarmschoten op de hoofdfortres waren gedaan, waren de schepen bij de Krommelijn.

Getuigen van de hoofdwacht hebben verklaard meer dan één boodschap van de Krommelijn ontvangen te hebben. Het is ook opgehelderd, waarom deze batterij niet gevuurd heeft. Er was nl. een order van kapitein Schmidt, dat de Krommelijn, de Waterforten, Rif en Punto Bravo, niet mochten vuren, vóór de hoofdfortres daartoe het sein gegeven had. Deze order, die uit zuinigheidsoverwegingen schijnt ingegeven te zijn, was van 10 October 1805 , en de gouverneur verklaarde bij een zijner verhooren, dat deze order hem geheel onbekend was.

Kapitein Schmidt was, naar hij zijn verslag begint, in zijn woning op Pietermaai, toen hij iets over vijf uur door een zijner dienstboden werd gewaarschuwd, dat vier schepen dicht bij het land waren. Hij liet zijn paard zadelen en reed stadwaarts. Bij de 
Krommelijn komende, zag hij, dat een schip met de Hollandsche vlag van den voortop reeds in de haven was en een ander den havenmond binnenzeilde. Zij oppasser, door hem vooruitgezonden om de poort te doen openen, kwam met het bericht, dat deze gesloten was en niet kon geopend worden. ,In dezelfde moment waaren de scheepen en de Hoofdfortres reeds aan het vuuren, zoo ook het Fort de Republiek". Daarheen begaf Schmidt zich.

Het is aannemelijk, dat de kapitein om iets over vijven gewaarschuwd is, naar wat hij zegt waargenomen te hebben, maar erg gehaast kan hij zich niet hebben, want volgens Engeler ${ }^{1}$ ), den commandant van fort Republiek, kwam Schmidt daar eerst om half acht aan. Engeler vertelt ook, dat hij reeds om vijf uur drie vaartuigen zag, waarvan hij niet kon onderscheiden, of het schepen of goletten waren, en daarom gaf hij geen waarschuwingssein. Om half zes waren er 4 en een er van lag al dicht voor den havenmond.

De luitenant Siecker had de wacht in het hoofdfort. In zijn morgenrapport deelt hij mee, dat de poort den vorigen avond, als steeds, om 9 uur was gesloten, en in den loop van den nacht geopend is voor de volgende personen: om kwart over negenen voor luitenant Balfour, te half tien voor den cadet-bombardier Schmidt en om half twee voor den chirurgijn-majoor der jagers Maes, den 1sten luitenant-kwartiermeester Lindenbergh ${ }^{2}$ ) en de tweede luitenants Becker ${ }^{3}$ ) en Ritter ${ }^{4}$ ) met hun vrouwen. Om half zes 's morgens was de poort weer geopend.

Als dit rapport juist is, wordt daarmee geloochenstraft de bewering van Teenstra, dat Pfeiffer, toen hij gewaarschuwd werd door de wacht - waarover straks - nog maar pas uit de armen van Bacchus in die van Orpheus zou zijn overgegaan en dus zijn woord aan den gouverneur niet zou gehouden hebben. Deze kwes-

1) Louis Engeler (zoo teekent hij, maar algemeen wordt hij Engler genoemd) was omstreeks 1780 te Gent geboren, van 1792 tot 1798 was hij ,,bij den keizer" als fourier, 1800-1805 canonnier, fourier, bombardier bij het 5 de bataljon artillerie op Curaçao, 1 Aug. 1805 2de luitenant bij het detachement 4de comp. artillerie aldaar.

${ }^{2}$ ) Carel Ehrenfeld Lindenberg, geboren omstreeks 1770 te Zittau in Opper-Lausitz, was sinds 1802 1ste luitenant-kwartiermeester bij het 5 de bataljon artillerie. Te voren had hij sinds 1792 de Oost-Indische compagnie gediend.

3) François Adriaan Beckers, geboren omstreeks 1780 in Venlo, was sinds 26 Jan. 1803 2de luitenant-provisioneel.

•) Hendrik Ritter, geboren in 1781 of 1782 te Amsterdam, was eveneens in 1803 tot 2de luitenant-provisioneel aangesteld. 
tie is ook voor de Hooge militaire vierschaar ter sprake gekomen. 11 November 1807 schreef de advocaat-fiskaal aan het college, dat Pfeiffer zich den avond en den nacht vóór de overgave op Pietermaai bij zekeren J. Hendricus in een talrijk gezelschap zou hebben bevonden en zich daar met den commandant der gewapende burgermacht ,op eene verregaande wijze in den drank te buijten zoude begaan hebben", en verzocht daarover L. Boyé te hooren.

Pfeiffer zelf heeft steeds volgehouden, dat hij na half negen niet uit het fort is geweest en op dat uur aan den adjudant Wolff ${ }^{1}$ ) een order tot het doen van een patrouille gegeven te hebben. Bij Boyé en Hendricus was hij tevoren geweest, maar overmatig gebruik van drank had hij niet gemaakt.

De onderofficieren van de wacht Martin en De Haas hebben voor commissarissen verklaard, dat de commandant den avond en nacht in het fort was geweest. Bekkerstee, assistent van Changuion, die diens geheimschrijver wordt genoemd, had van Hendricus gehoord, dat Pfeiffer daar tot 2 à 3 uur 's nachts was geweest, en vertrokken was ,,in een situatie, die hem geen eer aandeed". Majoor Hueck, de commandant van de burgermacht, was bij Hendricus , ,aan huis... besopen blijven leggen”. Doch Trapenberg, een sergeant der jagers, die tegelijk met Bekkerstee werd gehoord, en ook bij Hendricus geweest was en van 8 à 9 uur tot 12 uur gebleven was, had Pfeiffer niet gezien, maar er waren wel 300 menschen geweest. De straks weer te noemen onderofficier Klowasser heeft verklaard, dat de commandant om 8 uur binnen het fort was gekomen, en hij hem om 9 uur een rapport heeft uitgebracht, dit laatste in overeenstemming met een verklaring van den luitenant Siecker. Boyé ten slotte, die op Pietermaai recht tegenover Hendricus woonde, verklaarde, dat Pfeiffer tot 10 uur bij hem geweest was en daarna naar Hendricus gegaan was; hoe lang hij daar gebleven was, wist Boyé niet, wel, dat het talrijke gezelschap daar tot 3 uur, half vier, gebleven was. - Zoo is deze zaak niet opgehelderd geworden.

Om kwart over vijven naar zijn gissing, aldus Siecker, riep de schildwacht ,,corporaal van de wacht!' en deze korporaal bracht daarop den luitenant rapport, dat van Caracasbaai een kanonschot was gehoord. Siecker liet dit daarop terstond aan kapitein Pfeiffer rapporteeren.

Het schot van Beekenburgh is dus door de wacht in het hoofdfort wel ter dege gehoord, al kan het tijdsverschil van een half uur

1) Zie D. W. I. G. 25sten jg., blz. 12. 
niet opgehelderd worden, en het verhaal, dat dit sein door het oudejaarsnachtlawaai is overstemd, dat Euwens doet, berust op fantasie. Trouwens om 10 uur was een patrouille van de Overzijde teruggekeerd met rapport, dat aldaar de beste rust en stilte heerschte. Misschien was het toen echter nog te vroeg voor het oudejaarsavondrumoer. Blok had ten minste al eenige dagen tevoren met weerzin de gevaarlijke vreugdebedrijven, als het afschieten van voetzoekers en vuurwerk, gezien, en zijn verwachtng was toen ook, dat vele ingezetenen den overgang van het oude in het nieuwe jaar door overmatig ,drankmisbruik" schandelijk ten einde zouden brengen, doch hij had daartegen geen maatregelen willen nemen als pas opgetreden fiskaal om het oordeel te ontgaan de ingezetenen in hun vermaken te belemmeren. Alleen had hij den schout opgedragen rust en orde te bewaren en hem zoonoodig ten huize van den heer De Veer te komen waarschuwen. Om 1 uur was Blok naar huis en ter ruste gegaan.

Luitenant Siecker vervolgt, dat kort, nadat het schot van Caracasbaai was gerapporteerd, de schildwacht weer riep: ,,corporaal van de wagt!' De luitenant ging er nu zelf met den korporaal heen en hoorde het rapport van de batterij Krommelijn, dat een vaartuig van boven kwam. „Op hetzelfde moment was het betrokken lugt, edoch gissende meerder vaartuigen op de hoogte tusschen Krekesbaaij en Cornetsbaaij te zien". Siecker gaf den korporaal last Pfeiffer in persoon te rapporteeren, ,,die dan dadelijk naar de Batterij is gegaan om de zaaken te examineeren".

Om kwart voor zessen werd geschoten en alarm geslagen, en toen kreeg Siecker door den adjudant Wolff order om de poort te sluiten en met de wacht op de batterij te gaan bij de jagers.

Een van de vragen, die door commissarissen zeer bepaaldelijk zijn onderzocht, is die, of Pfeiffer één- of tweemaal rapport heeft ontvangen van de hoofdwacht. Merkwaardig hieromtrent is de verklaring van den sergeant Vincent Klowasser, oud 25 jaar, die in 1807 met de troepen van Curaçao was teruggekeerd en ten tijde van zijn verhoor bij het 3de of 7de regiment van linie in Holland diende. Van schoten van Caracasbaai wist hij niets. Wel had hij om twee uur schoten diep in zee gehoord. Driemaal kort na elkaar was er van half zes af een rapport van de Krommelijn gekomen over vaartuigen, die van boven kwamen. Honderd tellen eerder had de schildwacht van het kruitmagazijn die schepen al gerapporteerd, en Siecker had Klowasser dadelijk naar den commandant gezonden. Daar de oppasser van dezen niet kwam, had Klowasser zelf Pfeiffer wakker gemaakt en hem gewaarschuwd, 
dat er Engelsche schepen in het gezicht waren. De commandant had toen geantwoord, dat hij geen orders had, ,,waar hij zich naar reguleren moest", maar was dadelijk naar het kruitmagazijn gegaan en had daar onder de batterij het rapport van de Krommelijn persoonlijk in ontvangst genomen. Klowasser was zelf met Siecker naar de batterij gegaan, en beweert, dat hij twee schepen zag tegenover Cornetsbaai, die dus over een half uur bij de haven konden zijn. Siecker heeft dit laatste voor commissarissen bevestigd, behoudens dat dit volgens hem om kwart over vijven zou zijn geweest en de schepen toen nog tusschen Caracas- en Cornetsbaai waren.

De reeds genoemde Martin en De Haas verklaarden, dat Klowasser om omstreeks 5 uur het schot van Caracasbaai aan Pfeiffer was gaan rapporteeren, maar bevestigden, dat de commandant, toen een kwartier later het eerste rapport van de Krommelijn kwam, op de trappen van de batterij stond.

Van den luitenant Rabainne is een notarieele verklaring, dat er gezegd werd, dat Pfeiffer één- of tweemaal was gewaarschuwd, dat de vijand naderde, en toen geantwoord had, dat men zich dan alleen maar rustig had te houden, en dat, toen de Engelschen de batterij beklommen, de commandant gezien was op de batterij in hemd en onderbroek.

Pfeiffer zelf rapporteerde een paar dagen na den overval schriftelijk aan den gouverneur (en deze deelt mee, dat dit was in overeenstemming met zijn mondeling rapport dadelijk na des gouverneurs aankomst in het fort), dat hij om kwart over vijven bericht ontvangen had, dat er vier vaartuigen in zicht waren ,op de hoogte van een weinig boven de Cromme lijn en liggende na de Haven". Dadelijk liet hij het afgesproken sein voor den gouverneur doen en alarm schieten. Intusschen naderden de schepen met Parlementaire vlag op en kwamen onder het canon zonder dat er van de Batterijen Crommelijn, Nieuw Waterfort, het Rif en Punto Bravo hoegenaamd een schot is gedaan. De nieuwe batterij vuurde. Niettegenstaande dit, kwam het eerste schip zonder een schot te doen binnen de Haven, en werd beschoten door het Kenau Hasselaer en de Suriname, waarop het Engelsch schip de laag gaf. De andere kwamen ook binnen en beschoten het Fort zoodanig, dat ik door den Artillerie Lieutenant van Breningen ${ }^{1}$ ) rapport

1) Adrianus Johannes van Breeniegen of Breeningen, geboren 1765 of 1766 te Nieuwerkerk aan den I Jssel, was op 16-jarigen leeftijd bij de cavallerie, later bij de artillerie kanonnier en bombardier, sinds 1802 op Curaçao 1ste luitenant bij het 5 de bataljon artillerie. 
ontving, dat hij het op de nieuwe Batterij niet meer kon houden en vuurde niet meer".

Voor commissarissen van de vierschaar verklaarde Pfeiffer op veel punten anders. Hij gaf op te zijn gewaarschuwd door den sergeant van de wacht met rapport van het schot van Beekenburgh, en voegde daaraan toe, ,,dat er gedurende dien geheele nagt vuurwerken, die zeer sware slagen geven, sijn afgegeven". Op een andere vraag zei hij echter, dat hij dadelijk na het sein van het kanonschot rapport bekomen had door Vincent Klowasser, „,dat er geschoten wierd, en vaartuygen in het gezigt waren". Toch hield hij vol slechts eenmaal rapport te hebben ontvangen. Aanvankelijk ontkende hij werkeloos te zijn gebleven en geen de minste activiteit betoond te hebben. Dadelijk was hij naar de batterij het kruitmagazijn gegaan met den luitenant-adjudant Wolff, en in de schemering, terwijl het eenigszins regenachtig was, had hij vaartuigen gezien.

Een ordonnans had hij bevel gegeven om luitenant Van Breeniegen te roepen en dezen had hij gelast om dadelijk het seinschot voor den gouverneur te doen. Het lossen van dit schot had vertraging gekregen, daar ,,de canonniers de stukken niet spoedig konden doen lossen,... dat zij ook de sleutel van de amunitiekist van de Batterij de Waag niet konden vinden, immers dat sij dien kist niet spoedig konden open krijgen. Zegt nader, dat de Lonten niet goed in order waren". Hieraan ontkende Pfeiffer alle schuld, zijnde de zorg hiervoor de taak der artillerie.

Hij gaf op, dat er met dit alles wel een half uur zou verloopen zijn, voordat de sein- en alarmschoten gedaan waren, na eerst gesproken te hebben van een geruimen tijd, ,,so dat het klaar dag geworden was".

Toen de schoten eindelijk gelost werden, bevonden de vijandelijke schepen zich reeds in de haven.

Bij het binnenzeilen was op de schepen geschoten door een der Waterforten, ,,hebbende de Lieutenant Rappart ${ }^{2}$ ) selve het canon afgestoken", niet van de Krommelijn, het andere Waterfort, het Rif en Punto Bravo. Kapitein Schmidt had een order gegeven, dat er van die batterijen niet zou geschoten worden, voordat van de hoofdfortres geschoten was.

Ook was van het fort Amsterdam en de oorlogsschepen op de

1) Schmidt heeft voor commissarissen der vierschaar verklaard, dat alle batterijen in orde en van het noodige voorzien waren.

${ }^{2}$ ) Bernard Leonard'Rappard zie D. W. I. G. 24sten jg., blz. 375. 
Engelschen geschoten. Pfeiffer was toen op het hoofdfort op de nieuwe batterij, met ten hoogste 130 à 140 man, de kanonniers inbegrepen.

Op de nieuwe batterij had luitenant Van Breeniegen het bevel, op de waagbatterij de kapitein-adjudant Hagenberg ${ }^{1}$ ), maar deze laatste was niet bezet, omdat de sleutel van de ammunitiekist niet voorhanden was. Door de jagers waren drie schoten gedaan, daar de artilleristen, en ook jagers, gedeeltelijk waren weggeloopen. In het geheel bestond de bezetting uit 300 militairen, meest kleurlingen ${ }^{2}$ ).

Het vuur van de hoofdfortres had slechts korten tijd aangehouden, daar de nieuwe batterij, de eenige, die gevuurd had, verlaten was. Pfeiffer had nog tevergeefs getracht de manschappen weer naar de batterijen te brengen, want intusschen had de vijand van de desordre gebruik gemaakt om zich van de hoofdfortres meester te maken door die aan alle kanten tegelijk te beklimmen; hij ontmoette daarbij weinig tegenstand. Pfeiffer zelf werd dadelijk krijgsgevangen gemaakt. Het eigen volk gooide deels de wapens neer en sloeg die anderdeels stuk.

De luitenant Van Breeniegen heeft in zijn rapport voor Changuion meegedeeld, dat hij om half zes geroepen werd met de mededeeling, dat er 4 schepen in zicht waren. Hij was daarop naar de batterij achter het kruitmagazijn gegaan, had de waarschuwingsschoten voor den gouverneur gedaan en op de nieuwe batterij laten alarm-schieten. Op het eerste Engelsche schip, met de Hollandsche vlag van den voortop, had hij dadelijk met scherp geschoten, doch slechts eenmaal, daar de wind het schip voordeelig was. Daarop waren het tweede en het derde schip gekomen ,onder eene goede Regenbuij", en nog tweemaal had hij gevuurd. Toen een fregat vlak vóór de batterij was gaan liggen, had men daar bij gebrek aan borstwering of andere beschutting niet kunnen blij-

1) Johan Philip Hagenberg, geboren in 1752 of 1753 te Steenbergen in Pruissen, diende sedert 1773 de West-Indische compagnie. Als soldaat begonnen, was hij sedert 1804 kapitein-adjudant bij het inlandsch korps artillerie. In 1804 had hij al pensioen gevraagd.

") In het „Beknopte plan van defensie” van majoor Schmidt en „Plan van organisatie van de artillerie” (1806) wordt meegedeeld, dat er bij de artillerie waren: 100 Europeanen, 49 Curaçaosche blanken, 46 kleurlingen en 114 vrij geboren negers. Verder wordt daarin gezegd: ,Bij de 2e comp. Jagers en detachement van de 4de comp. artillerie bevinden zig bij de Presente en Gedetacheerde verscheide verminkte, Inpotente en niet tot Fatigues bekwaame Manschappen". 
ven staan, tenzij men de weinige manschappen nutteloos had willen opofferen, maar toch was eerst na drie lagen schroot van de fregatten de batterij tot zwijgen gebracht. Twee vijandelijke schepen, zegt Van Breeniegen, gingen naast onze oorlogsschepen liggen en begonnen deze op de hevigste wijze te beschieten. Toen Van Breeniegen aan Pfeiffer meedeelde, dat de Engelschen troepen aan land zetten, zei de commandant: ,,wat zullen wij daaraan doen, mijnheer? wij moeten het Hoofdfortres verdedigen". De luitenant ging daarop naar zijn batterij, die de Engelschen al aan het beklimmen waren. Daarop vervoegde Brisbane zich bij hem en vroeg naar den commandant.

En nu over deze gebeurtenissen de belangrijke brief van den fiskaal Blok van 1 Juni $1807^{1}$ ), waaruit reeds een en ander is meegedeeld.

Blok begon zijn ,,verslag" met zijn slotsom: Het eiland is in des vijands macht geraakt ,op eene lafhartige en onteerende wijze, door verregaand plichtverzuim en de ongehoordste onachtzaamheid". Wien dit verwijt in de eerste plaats gold, zal spoedig blijken.

Ongeveer half zes in den morgen van 1 Januari 1807 had hij vuren gehoord en overal alarm-slaan, waarop hij zich aangekleed en naar het fort begeven had. Daar gekomen, zag hij twee vijandelijke schepen binnen de haven en twee andere „zeer nabij”. De gesloten deuren van het fort werden voor hem geopend, en hij trof daar den commandant Pfeiffer met het garnizoen onder de wapenen. Op zijn vraag, of hij eenige orders van den gouverneur had, antwoordde de commandant: ,ik zal het fort defendeeren”, waarop de fiskaal zei: ,,dat is goed en doet uwen plicht". Onmid-

1) Blok was 9 Januari met de ,Arethusa” onder bevel van Brisbane van Curaçao vertrokken en 15 Januari op Jamaïca aangekomen. Daar deed de admiraal Dacres niet gestand de toezegging van Brisbane om Changuion c.s. met een ,, koningsfregat" naar Holland te laten brengen. Blok verkoos toen per particuliere gelegenheid over New York te reizen. 10 Februari vertrok hij met de ,'Hibernia”, kapitein Henry Toffet, leed schipbreuk en kwam eerst 14 Mei te „Nieuw-Utrecht op Lang Eiland bij Nieuw Jork'. Hij gaf er de voorkeur aan daar te blijven, ten einde onnoodige reiskosten te vermijden, want hij hoopte op herplaatsing in de West, en noemde, als door hem begeerd, de fiskaalsplaats op St. Eustatius. Hij werd in 1808 op Batavia geplaatst en kreeg vergoed $f$ 4.000.- reiskosten van N. Amerika daarheen. Hij was een vurig patriot. Hij had ook reeds 3 Januari van Curaçao geschreven en dien brief aan kapitein Lydiard meegegeven, die 5 Januari met de Hollandsche troepen op zijn schip ,Anson" vertrokken was. 
dellijk daarop verliet Pfeiffer hem, wat Blok toen toeschreef aan een wel geplaatsten ijver om de noodige bevelen tot een krachtdadige verdediging met den meesten spoed te geven.

Kort daarna - Pfeiffer vermeldt dit als voorgevallen nadat hij de mededeeling van Van Breeniegen, dat hij het op de nieuwe batterij niet houden kon, ontvangen had - kwam de adjudant Boyé ${ }^{1}$ ) en een ander, aan Blok onbekend, persoon met een geblinddoekten Engelschen officier tusschen hen in, die een brief van den Engelschen bevelhebber, aan den fiskaal en den raad gericht, overhandigde, met den eisch om het eiland binnen 5 minuten over te geven, in welk geval de eigendommen en bezittingen der ingezetenen ontzien zouden worden ${ }^{2}$ ).

Blok deelde dit aan Pfeiffer mee, en daar tot dusver nog niets tegen den vijand ondernomen was, en de 4 fregatten reeds binnengezeild waren, vroeg hij dezen stellig te mogen weten, of door het aanwenden van de meest gepaste en krachtigste middelen de vijand gedwongen zou kunnen worden van zijn onbillijken eisch en verdere onderneming af te zien. De commandant riep daarop de officieren bijeen en kreeg van den luitenant der artillerie Van Breeniegen een ontkennend antwoord op zijn vraag, of deze met de door hem gecommandeerde nieuwe batterij nog eenige defensie zou kunnen doen. ,Dat antwoord had ik van U niet verwacht”, zeide Pfeiffer, waarop de luitenant repliceerde: ,Ik kan van de nieuwe batterij geen gebruik meer maken, omdat dezelve geheel ongedekt is, en hadt gij mij op mijne veelvuldige aanzoeken, bij $\mathrm{U}$ gedaan, de benoodigde zandzakken gegeven, zoude ik zoodanig een antwoord niet gegeven hebben".

1) Over Ludwig Boyé zie men D. W. I. G., 25sten jg., blz. 10 e.v.

2) Een afschrift van den brief, die volgens Pfeiffer door den commies Gorsira werd vertolkt, ligt in het archief van den Raad der Amerikaansche koloniën (no. 179) en luidt:

On board his Majesty's ship Arethusa 1st January 1807.

The British squadron are here to protect and not to conquer your and to preserve your Lives, Liberty and property.

[If a ?] shot is fixed at any one of my squadron after this summons, I shall immediately commence Bombarding your Town and Storming your batteries. You have five minutes to accord to these Terms.

I beg you will accept my highest consideration and am

$$
\text { Sir! Your most obedient and very }
$$

Humble Servant

$$
\text { C. Brisbane }
$$

",To the Worshipful The Fiscal and Magistrates of Curaçao". 
Toen hij dat hoorde, beklom Blok de batterij, die reeds verlaten was, vond die geheel ongedekt en zoo gesteld, dat van daar door de positie, die de vijandelijke schepen genomen hadden, geen verdediging meer kon gedaan worden. Teruggekeerd, vond hij alles in de grootste verwarring en Pfeiffer besluiteloos. Op Bloks verzoek zond Pfeiffer luitenant Beckers naar den vijandelijken bevelhebber met een verzoek om vier uren uitstel om den raad bijeen te roepen en dan schriftelijk op den eisch te antwoorden.

$\mathrm{Na}$ het vertrek van dezen luitenant zag Blok tien tot twaalf Engelschen met een ,,gedeguiseerden” (nl. geblinddoekten) officier, die later bleek kapitein Lydiard van de „Anson” te zijn, uit de, blijkbaar ongedekte en geopende, avenuen van de batterij achter het fiskaalshuis in het fort komen, waarop alle jagers en de adjudant Wolff hun ,busschen" neerwierpen. Blok sprak Lydiard aan, en werd door dezen bij den Engelschen bevelhebber gebracht, die met Pfeiffer op de wallen was. Hij kreeg vergunning om den raad bijeen te roepen.

Niet ver van de zijpoort, waardoor Blok het fort verliet, ontmoette hij den gouverneur Changuion met diens familie en keerde met hen in het fort terug.

Tot zoover voorloopig Blok.

Pfeiffer schrijft in zijn rapport nog, dat na het vertrek van luitenant Beckers de Engelschen van alle kanten in het fort gegekomen zijn, waarop hij met de jagers naar de batterij de Waag was gegaan, vanwaar nog 2 à 3 kanonschoten waren gedaan. Kapitein Krapf ${ }^{1}$ ) werd daarop door Pfeiffer naar de batterij de Halve maan gezonden, maar deze bleek reeds door de Engelschen bezet te zijn. Zelf wilde de commandant naar de Nieuwe batterij gaan, toen luitenant Van Breeniegen hem zeide, dat de Engelsche bevelhebber, die reeds met een zwaar detachement daar was, naar den garnizoenscommandant vroeg. Brisbane eischte nu de overgave van het fort Republiek, wat Pfeiffer weigerde, waarop de Engelschman dreigde met vuur te zullen geven van zijn schepen. Daarop had Pfeiffer den luitenant Balfour van Burleigh met een Engelsch detachement naar het fort gezonden.

Het rapport besluit met de mededeeling, dat op het alarmschieten buiten den fiskaal niet één burger in het fort was gekomen.

Voor commissarissen der vierschaar heeft Pfeiffer toegegeven, dat hij reeds eerder den korporaal Bosch naar fort Republiek ge-

1) Zie D. W. I. G. 24sten jg., blz. 375. 
zonden had met order om niet meer te vuren. Hij had dat gedaan op aanraden van luitenant Van Breeniegen - die dit voor commissarissen ontkend heeft - en van andere officieren. Desgevraagd erkende hij dit buiten voorkennis van den gouverneur te hebben gedaan, en zeide te meenen daartoe gerechtigd te zijn, omdat het fort Amsterdam over was en fort Republiek het niet meer houden kon. Nu gaf hij toe, dat hij daartoe onbevoegd was geweest, omdat hij onder de orders van den gouverneur en opperbevelhebber stond en zelf krijgsgevangen was, maar hij had dat toen niet ingezien.

De gouverneur Changuion heeft van zijn wedervaren een en andermaal verslag gedaan. Den 3den Januari 1807 schreef hij in het kort den minister van Koophandel en Koloniën, dat vier zware Engelsche fregatten de haven hadden ,,geforceert", waarbij de commandant der navale macht, eenigen van ,,ons volk" en eenige inwoners waren gesneuveld, en de zeeofficier Van Nes zwaar gekwetst was. Hij voegde eraan toe, dat alles ,,volstrekt buiten (z)ijn schuld" was. Op 1 Februari 1807 deed Changuion van Kingston op Jamaica den minister toekomen zijn „Hoofdzaakelyk Relaas, of voorloopig Raport van het voorgevallene op Curaçao op den 1 Januari 1807 bij gelegenheid van zeszelfs verovering door de Engelschen - voor zoo verre mij zulks bij eigene bevinding en ontfangen Raport bekend is". Later is hieraarı een zeer uitvoerig verslag van het verblijf op Jamaica en de verdere reis naar Holland toegevoegd. Met het reeds genoemde, niet-gedagteekende, „,relaas” (blz. 197) vormt het, voor zoover niet anders wordt vermeld, den grondslag van de volgende samenvatting.

Om 5 à 10 minuten vóór zessen op den nieuwjaarsmorgen werd de gouverneur gewekt door een kanonschot, beantwoord door het fort Republiek; hij zag daar de Hollandsche vlag verkeerd geheschen. Zijn vermoeden was, dat eenige schepen gezien waren of een parlementaire sloep binnengekomen was. Dadelijk kleedde hij zich en binnen 10 minuten na het schot was hij van wal gestoken. Hij beloofde den roeiers een goede belooning voor een snellen overtocht. Na vijftig pagaaislagen hoorde hij een sterke kanonnade en eenige schoten van het fort Republiek. Changuion verdubbelde de toegezegde belooning voor nog meer spoed. De kogels vielen bij de poort in het water. De gouverneur dacht aan een beschieting van de haven. In hun vrees voor de kogels hielden de negers schuin aan op de rots, waarop fort Republiek lag, maar Changuion gebood hen in rechte lijn door te varen. $Z$ ij bereikten 
de hoek van de klip van Basden, doch de roeiers wilden niet voldoen aan het bevel om door te varen naar den ingang van het Waaigat, waar het zoogenaamde huis van Primet stond. Intusschen had Changuion gezien, dat vijandelijke schepen rustig met neerhangende zeilen en uitgeworpen ankers in de baai lagen vóór de hoofdfortres met parlementaire vlaggen, en hij maakte de gevolgtrekking, dat het sein voor hem te laat gegeven was, want er waren sindsdien nog maar 25 minuten verloopen. Changuion was dus in een kwartier niet verder dan de werf van Basden gekomen.

Daar aankomende, zag hij het laatste schot met schroot van een der Engelsche fregatten vallen. Door den onwil der roeiers moest de gouverneur hier uitstappen, en met een ,,gemeene" pont, die daar juist lag, liet hij zich dwars over de haven zetten naar de klip van Van der Meulen, om inlichtingen in te winnen naar den toestand in de hoofdfortres Ten huize van Th. Jutting ${ }^{1}$ ) trof hij Matthias Schotborgh ${ }^{2}$ ), die echter niets wist.

Omdat het vuren niet werd voortgezet, stelde de gouverneur zich voor, dat men in de hoofdfortres nog aan het capituleeren of parlementeeren was. In haast liet hij zich overzetten naar den hoek van het Waaigat, het huis van Primet, in de hoop ongemerkt het fort binnen te komen, ,,om het ergste te prevenieeren".

Hij ging aan land en vond het Bloedfort op den hoek der stad met Engelschen bezet; verschillende huizen langs den waterkant waren door kogels geteisterd. Nu vernam hij spoedig, dat de Engelschen meester van het hoofdfort waren en van den persoon van den commandant. Op weg naar het oostelijk sortiepoortje ontmoette hij den fiskaal. Het treft, dat Changuion er niets van vertelt, dat hij met zijn familie was; uit zijn verhaal zou men kunnen afleiden, dat hij den tocht alleen gemaakt had, maar Blok zegt het anders en ook in de Engelsche mededeelingen is daarvan sprake. Voor de vierschaar heeft de gouverneur erkend, dat hij was teruggegaan met zijn vrouw, zijn zoontje en den assistent ${ }^{3}$ )

1) D. W. I. G. 24sten jg., blz. 368.

2) De naam Matthias Schotborgh komt in dien tijd veel voor. Misschien is deze degeen, die in 1816 ontvanger-generaal werd, in 1819 wegens wanbeheer werd ontslagen en in 1821 overleed.

s) Bekkerstee verklaarde aan commissarissen der vierschaar, dat de gouverneur, mevrouw Changuion en hun zoontje - twee dochters waren op Bleyn achtergebleven - binnen 5 minuten na het seinschot in het pontje stapten. Hij zag toen bramzeilen van een vaartuig in de haven. Aan den wal had de gouverneur nog een ontmoeting met luitenant Balfour, die op weg was naar fort Republiek, die dit aan den gouverneur vertelde maar geen orders afwachtte. 
Bekkerstee. De fiskaal deed verslag van alles, wat hij meegemaakt had, en van hem hoorde de gouverneur ook, dat vóór de luitenant Beckers het hoofdfort had verlaten om 4 uur uitstel te vragen, de Engelschen waren begonnen de stad te beschieten, de batterijen van de hoofdfortres te beklimmen en in weinige minuten zich van alles meester te maken, ,zijnde de Engelsche commandant zelve aan het Hoofd van zijn volk de nieuwe batterij op gekomen".

Blok overhandigde den gouverneur ook een brief, voor dezen bestemd, luidende

To his Excellency The Governor of Curaçao. His Britannic Majesty's ship Arethusa of Curaçoa Jan. 1st. 1807.

I have the honour to inform Your Excellency that the squadron under my orders is now placed before Your Town and Batteries.

I give Your Excellency five minutes to accord to my Terms before I commence bombarding your Town and storming the Batteries. Your Excellency shall continue civil governor. The Magistraty shall excercice their authority, and all private property protected.

I beg You will accept my high consideration, and am Your Excellency's most obedt. humble servant

\section{Brisbane}

Changuion liet daarop den bode den raad bijeenroepen met de commandanten van zee- en landmacht en van de gewapende burgermacht. Zelf ging hij met Blok de sortiepoort binnen en ontmoette Brisbane. Hij vond in het fort de Engelschen, en de jagers ontwapend. Het gouvernementshuis was rijkelijk beschadigd en met Engelsch krijgsvolk bezet. Ook tegenover den gouverneur deed de Engelsche commandant onder bedreiging de stad te zullen beschieten zijn eisch gelden van onmiddellijke overgave van het fort Republiek, terwijl Changuion daartoe slechts bereid was bij ,honorable capitulatie”, en ten slotte won Changuion het pleit. Volgens Bekkerstee is onder deze besprekingen mevrouw Changuion flauw gevallen. Pfeiffer had nog de onkieschheid gehad tegen mevrouw Changuion te zeggen, dat zij nu spoedig in Holland zou zijn, waarop zij antwoordde, dat zij dit zóó nooit begeerd had.

Over de voorwaarden der capitulatie is beraadslaagd door den gouverneur en de kapiteins der jagers Pfeiffer en Krapf, luitenant Van Breeniegen van de artillerie, majoor Hueck van de gewapende burgermacht, de fiskaal mr. Blok, terwijl de raadsleden 
Cancrijn ${ }^{1}$ ) en Van $\mathrm{Eck}^{2}$ ) eerst gedurende de vergadering kwamen, en de secretaris Wenckebach eveneens aan de bespreking deelgenomen heeft. Van de zeemacht was derhalve niemand verschenen en ook waren weggebleven mr. P. B. van Starckenborgh ${ }^{3}$ ) C. Berch, vroeger (1803-1804) met De Veer als commissarissen provisioneel met de directie belast, A. A. Beutner ${ }^{4}$ ) en $\mathbf{R}$. 't Hoen, raadsleden.

De gouverneur stelde de vraag, of het fort Republiek, zooals de zaken stonden, in staat zou zijn den vijand te noodzaken zijn behaalde voordeelen te verlaten en het eiland weer geheel in onze macht te brengen. Allen beantwoordden die vraag ontkennend.

Blok deelt nog mee, dat hij eerst naar huis was gegaan, zijn woning en de in de nabijheid gelegen huizen door kogels zwaar beschadigd, een der dienaars van de justitie vóór zijn deur doodgeschoten had aangetroffen, en zijn familie in den kelder, en bij De Veer inlichtingen gevraagd had over de sterkte van het fort Republiek, die luidden, dat het, behoorlijk voorzien zijnde, den vijand veel nadeel zou hebben kunnen toebrengen, maar het tegen een aanvallende vijand niet lang zou kunnen uithouden. Volgens hem was het op zijn raad geweest, dat Changuion geweigerd had aanstonds in te gaan op den eisch van Brisbane en ook van Lydiard tot overgave van het fort Republiek, en had hij toen de gedachte van een behoorlijke capitulatie als voorwaarde voor de overgave geopperd.

In de vergadering was hij daarmee dan ook weer voor den dag gekomen. Wenckebach en Changuion vielen hem daarin bij. Blok liet nog aanteekenen, dat hij zich het oordeel over hetgeen voorgevallen was voorbehield ${ }^{5}$ ).

Tot tweemaal toe was de vergadering gestoord door Brisbane, die nog eens onmiddellijke overgave eischte, maar ten slotte een half uur tijd gaf om de voorwaarden eener capitulatie te ontwer-

1) B. A. Cancrijn, 1753-1837, was in 1780 als koopman op Curaçao gekomen. Hij was lid der firma Cancrijn en Jutting, en bekleedde verschillende openbare ambten als het lidmaatschap van den raad van politie, was weesmeester en later lid van het gemeentebestuur.

2) Christiaan Aemilius van Eck, geboren te Sluis, was boekhoudergeneraal en als zoodanig raadslid.

$\left.{ }^{3}\right)$ Carthagena, waar hij woonde, lag aan de Overzijde.

4) Hij was nog, of sinds 1816 weer, raadslid, toen hij in 1819 op een reis naar New-York overleed.

s) Van deze vergadering is een afzonderlijk proces-verbaal opgemaakt, aanwezig in portefeuille 179 van het archief van den Amerikaanschen raad.

West-Indische Gids XXV 
pen. Aldus geschiedde en te 9 uur 40 werden die door Changuion en Brisbane geteekend. Changuion noemt ze uitdrukkelijk ,,preliminaire" voorwaarden.

$\mathrm{Zij}$ luidden volgens het verbaal der vergadering:

Art. 1. Dadelijk zal het Fort Republiek overgegeven worden aan de Britsche Macht, het Guarnisoen met krijgseer uitmarcheren, de wapens weerleggen en zig krijgsgevangen geven.

Art. 2. Het Hollandsch Guarnisoen op het Eiland Curaçao zal krijgsgevangen zijn, en van wege $Z$ ijne Brittannische Majesteit naar Holland worden getransporteerd, en niet wederom dienen in dezen oorlog voordat dezelve uitgewisseld zijn, waartoe de officieren derzelver woord van eer verbinden.

Art. 3. Ten opzichte der Hollandsche oorlogschepen zullen de Equipagien als in Art. 2 worden verzonden, en de officieren insgelijks hun woord van Eer verbinden.

Art. 4. Alle Politique Ambtenaren zullen in derzelver Posten blijven des verkiezende, en de anderen naar Holland worden gezonden van wegen $Z$ ijne Brittannische Majesteit.

Art. 5. Alle Inwoonders, Kooplieden, Planters en verdere In en opgezetenen als ook (Neutrale $\left.{ }^{1}\right)$ ) Vreemdelingen, zig op dezelve bevindende, zonder onderscheid van Couleur en denkwijze, zullen in hunne personen en eigendommen gerespecteerd worden.

Art. 6. Alle de Koopvaardijschepen en Vaartuigen, in deze Haven liggende, van wat Natie zij ook zouden mogen zijn, zullen het wettig Eigendom blijven van hunne Bezitter of Bezitters.

Art. 7. Op grond van deze Praeliminaire zal er binnen 3 dagen een definitieve capitulatie worden geslooten.

Aldus overeengekomen tusschen ons Gouverneur en den Commandant van zijne Britsche Majesteits Force den 1 Januarij 1807.

P. J. Changuion

gouverneur des Eilands Curaçao
Charles Brisbane

Commandant of his

Brittanick-Majesteits Schip in Curaçao

Hoe was het op fort Republiek gesteld? Uit het rapport van den commandeerenden officier, luitenant Engeler, is reeds iets meegedeeld. Het sein voor den gouverneur heeft hij onmiddellijk doorgegeven. Een tijd geeft hij daarvan niet op, maar uit zijn relaas blijkt, dat het over half zes moet geweest zijn. Hij zag ook, dat de gouverneur zich ,,direct" in de pont begaf.

Verder nam hij waar, dat de nieuwe batterij drie schoten deed op het eerste Engelsche fregat, en zelf deed hij daarop, toen het met de Hollandsche vlag aan den voortop de „Kenau Hasselaar” voorbij was en de Engelsche schepen dit de volle laag gaven, 6070 schoten.

$\left.{ }^{1}\right)$ Dit woord is later ingevoegd. Zie hierna. 
Kapitein Schmidt had op weg naar fort Republiek den burgerkapitein Obergh met 2 officieren en 13 man van de burgermacht ingehaald, die dezelfde bestemming hadden, omdat zij het hoofdfort niet meer hadden kunnen bereiken. Hij stelt hun aankomst aldaar vroeger dan Engeler, tusschen 6 en 7 uur. Op dat oogenblik zwegen alle batterijen. Schmidt nam het commando over. Kort daarna kwam korporaal Bosch van de artillerie met de order van Pfeiffer, dat niet meer gevuurd mocht worden, en ,,iets naderhand"', volgens Engeler om 8 uur, luitenant Balfour en een Engelsch officier in een boot met 60 gewapende manschappen. De Hollandsche officier, die alleen werd te woord gestaan, bracht de boodschap van Pfeiffer, dat het fort aan de Engelschen moest worden overgegeven, en zeide, ,,dat reeds alles over was en de Engelschen de stad en de andere batterijen bezet hadden. Aldus stond Schmidt hem te woord: ,Zeg aan commandant Pfeiffer, dat ik het fort Republiek niet overgeef zonder schriftelijke order van den gouverneur en zonder een voordeelige capitulatie; dat ik het liever in de lucht zal laten vliegen". Intusschen bleek, dat er nog slechts 1 vat vleesch, 1 vat spek en 3 ankers rum in het magazijn waren en in het geheel geen brood. Schmidt zond een burger uit om dat op Schaarloo of Pietermaai, die nog niet door de Engelschen bezet waren, te gaan koopen. Het was toen ongeveer 9 uur geworden. Alles werd in staat van tegenweer gebracht, en een uur later een order naar de batterij Waakzaamheid gezonden aan den bombardier Van der Grijp om die batterij tot den laatsten man te verdedigen, zoolang op fort Republiek de Hollandsche vlag zou blijven waaien, en de stukken van de batterij Wreeker te demonteeren, zoodra hij den vijand daarheen zag oprukken.

Tusschen 12 en 1 uur kwam er weer een gewapende boot bij fort Republiek. Luitenant Van Breeniegen ging met een Engelsch officier, voorafgegaan door een witte vlag den berg op, en overhandigde deze schriftelijke eigenhandige, order van Changuion:

De Gouverneur- gelast den commandant van het Fort Republiek, hetzelve Fort over te geven aan de Brittische Macht, moetende het Guarnisoen met Krijgseer uitmarscheeren, de wapens nederleggen en zich krijgsgevangen geven.

Ten Gouvernements huijzen op Curaçao den 1en Januarij 1807.

$$
\begin{aligned}
& \text { P. J. Changuion } \\
& \text { Gouverneur }
\end{aligned}
$$

Na wel overlegd te hebben - brood was er niet gekomen gaf Schmidt het fort over aan den Engelschen officier. Het garnizoen is ,"met slaande trom en vliegende Hollandsche vlag uitge- 
marcheert". Vóór het fort werden de wapens neergelegd. Schmidt, die klaagt over zijn ,,gebrekkig lichaam" verhaalt ten slotte, dat hij tot 5 uur in het fort heeft moeten blijven en toen door vier Engelsche matrozen van den berg in een pont gedragen werd, en zoo zich naar het fort Amsterdam begeven heeft.

Voor de buitenposten heeft Changuion aan Pfeiffer, den garnizoenscommandant, een gelijke order als voor fort Republiek gegeven. Van een tweetal weten wij, hoe het verloop der zaak daar geweest is.

Luitenant Hendriks op Beekenburgh vernam tusschen 8 en 9 uur in den morgen, dat haven en hoofdfortres genomen waren, en om 4 uur, dat fort Republiek zich had overgegeven. Een uur later bemerkte hij verslapping van den geest der bezetting van zijn fort. Toen hij 3 of 4 man vermiste, sloot hij de poort, maar de manschappen ,begonnen van alle kanten over onbegrijpelijke stijle klippen van het Fort te springen"'. Hij trok zijn sabel, sloeg er op in, maar slaagde er niet in de vluchtenden tegen te houden. Twee of drie vielen hem van achteren aan, hielden zijn armen vast en maakten zich meester van zijn sabel, zonder dat hij er iets tegen kon doen. Zijn pistolen hadden zij reeds tevoren uit zijn huis gehaald. Om 7 uur 's avonds was hij geheel alleen op het fort. Eerst 3 Januari 's morgens kwam een Engelsche brik, die een gewapende boot uitzette. Hendriks'vuurde zijn gansche batterij af, streek de vlag en gaf het fort over aan den kapitein van de brik.

De 1ste schrijver der marine Plats verhaalt, dat hij aan wal was met den luitenant Quast ${ }^{1}$ ). Omstreeks 6 uur werd hij door 3 of 4 kanonschoten gewekt, en uit zijn venster zag hij een schip met de Hollandsche vlag aan den voortop in den mond van de haven en verder binnenzeilen, gevolgd door een tweede. Hij kleedde zich, ging naar den Waterkant (hij was dus op Otrabanda, de Overzijde) en zag 4 schepen in de haven, alle met een Hollandsche vlag aan den voortop en de Engelsche aan de gaffel. Hij zag, dat de Hollandsche schepen door de Engelsche geënterd werden en hun vlaggen gestreken werden. Daar de pontjesnegers gevlucht waren, kon hij niet aan boord van zijn schip komen, en daarom begaf hij zich met luitenant Quast naar het fort Waakzaamheid op den berg met nog drie man, die zij onderweg meegenomen hadden. $\mathrm{Zij}$ troffen daar 12 à 14 burgers en kanonniers. Er kwam daar een

1) Zie D. W. I. G. 25sten jg., blz. 2. 
Engelsch officier met ,,een klijn stukje Papier ... van de volgende inhoud ,,if you don't hoist to the English Coclar immediately I shall take the fort with storm and give no any men quarter. Brisbane"'". Plats gaf op verzoek van den commandeerenden officier den Engelschman een afwijzend antwoord. Vervolgens zag hij de Engelsche vlag op de hoofdfortres hijschen. Er kwam een man van fort Republiek met een briefje van Kapitein Schmidt, dat een aansporing inhield om zich te verdedigen, zoolang de Hollandsche vlag daar zou blijven waaien. 's Middags ging die vlag neer.

Deze laatste is een der verklaringen van de zeeofficieren in het rapport-Verhuell, aangevuld uit een nadere verklaring van 24 Mei 1807, te vinden bij de gedingstukken van de Hooge militaire vierschaar. Ook van de verklaringen der andere officieren volgt hier een samenvatting.

De kapitein-luitenant Slotendijck begint zijn verhaal om 6 uur 's morgens op 1 Januari 1807 (een ander rapport bevat zijn wedervaren van $1801 \mathrm{af}$ ). Op dat uur ongeveer, zegt hij, is de aanval begonnen. Hij ging op het halfdek, hoorde twee schoten vallen, en zag een zwaar fregat onder Engelsche vlag met een Hollandsche vlag aan den voortop om den hoek van de haven komen, waarop hij het volk beval bij de stukken te gaan. Toen kwamen Evertsz en De Quartel aan boord, en eerstgenoemde nam het bevel over de kuilbatterijen op zich. Slotendijck liet van het halfdek op het vijandelijk fregat, dat met ruimen wind de haven binnenzeilde, vuren. Het fregat schoot niet terug en ging voor het Waaigat liggen. Daarop liet Evertsz het volk van de halfdeksche batterij tot versterking naar de kuilbatterijen komen. Een tweede fregat, zwaarder nog dan het eerste, kwam binnen, en hierop speelde de kuilbatterij. Het Engelsche fregat presenteerde zijn stuurboordsbatterij en maakte daarmee een verschrikkelijk vuur. Een derde fregat schoot de ,,Suriname” van stuurboord opzij, en een vierde ging voor het fort Amsterdam liggen, sterk vurende op de „,Kenau Hasselaar". Evertsz sneuvelde door de eerste laag van het tweede fregat. Het volk, dat eerst gewillig was, was moeilijk bij de stukken te houden en sprong over boord, toen de „Kenau Hasselaar” niet werd gesteund van de landzijde. De vijand enterde de „Kenau Hasselaar" en haalde de Hollandsche vlag neer. Drie personen waren gesneuveld, evenveel gekwetst, en eenige, onder welke Slotendijck, door een schampschot van schroot langs rechterbeen en dij licht gewond. Dat er zoo weinig gesneuvelden waren, ver- 
klaart hij als gevolg van de weinigen, 50 man, die aan boord gebleven waren.

Luitenant De Quartel, die aan den wal was, verhaalt, dat hij om zes uur van eenige inwoners hoorde, dat er 4 schepen in zicht waren. Op weg naar zijn schip zag hij de vlag hijschen op het fort Republiek en daar twee schoten lossen. Hij zag 4 fregatten met de Hollandsche vlag aan den voortop, , ,vis a vis van het Waterfort". De ,Arethusa", tot het Waaigat doorgeloopen, hield zich bezig met dit fort, vanwaar geen schot terug gehoord werd. Op het fort Amsterdam zag hij geen sterveling bij de batterijen. Ten aanzien van het aan boord van de „Kenau Hasselaar” door hem meegemaakte stemt De Quartels verklaring overeen met die van Slotendijck.

De verklaring van den chirurgijn-majoor Tappert $\left.{ }^{1}\right)$ bevat alleen dit bijzondere, dat hem om ongeveer vijf uur (volgens zijn ander rapport ,"met den dageraad”) op het halfdek van de „,Kenau Hasselaar" door de matroos op den uitkijk toegeroepen werd, dat er eenige schepen, later 4, kort onder den wal in zicht waren, hij ,omtrent dien tijd" twee signaalschoten van het fort Republiek hoorde en kort daarop op de „Kenau Hasselaar” alarm geslagen werd. Hij spreekt van 5 gewonden, van welke er 2 stierven. Evertsz was ,door een kanons Kogel 't halve Hooft... afgeschooten".

De kapitein Van Nes zegt, dat hij met verlof aan land was, 10 minuten van de stad, toen hij om 6 uur werd gewaarschuwd, dat er 4 schepen achter Pietermaai dicht onder den wal waren. Hij ging aan boord en verwonderde zich, dat er van de Krommelijn niet geschoten werd. Ook van het Waterfort werd geen schot gedaan. Zijn bemanning, voor zoover kleurlingen en inlanders, sprong overboord. Eén man van de "Suriname" werd door een schot van fort Republiek gedood. Van Nes en Moqué werden gewond. De cadet Beutner sneuvelde. De „Suriname” werd geenterd en de Hollandsche vlag neergehaald. 20 tot 25 minuten had het gevecht geduurd. Vier mannen waren gesneuveld en eenigen gekwetst.

Het rapport van den luitenant Hulsebos ${ }^{2}$ ) levert niet veel bijzonders op. Hij was aan boord van de „Suriname” en werd om kwart voor zessen door luitenant Edema gewaarschuwd, dat er 4 schepen in zicht waren. Hij zag deze binnenzeilen, en hoorde bij de komst van het eerste fregat in de haven twee schoten van het fort

1) Zie D. W. I. G. 26sten jg., blz. 19.

?) Id., blz. 16 . 
Amsterdam vallen, beantwoord door het fort Republiek. Hij vertelt ook dat Evertsz nog aan boord geweest is om de bemanning moed in te spreken en van daar naar de „Kenau Hasselaar” ging.

Tot zoover het verhaal van ooggetuigen en medewerkers aan dit treurspel, die in hun onderling overeenstemmende verklaringen een gansch ander beeld van het geheel en van de onderdeelen geven dan de zegslieden van Phoel, toen deze twintig jaar later zijn verhaal in De Curaçaosche courant gaf. Het blijft met dit al een wel zeer somber beeld.

Laten wij daarover nog eens de fiskaal Blok aan het woord.

,Zoo is dan" - aldus onderbreekt Blok zijn verhaal der gebeurtenissen - , ,dat schoone Eiland, hetwelk van alle behoorlijke middelen van verdediging genoegzaam voorzien was, zonder dat op de acht dagen tevoren gedane sommatie eenig acht geslagen was, zonder dat sedert dien tijd de nodige voorzorg tot weering van vijandelijke aanvallen genomen is geworden, en zonder het doen van eenige defensie, behalve hetgeen door 's Konings vaertuigen en het Fort Republiek gedaan is, op eene schandelijke wijze aan den vijand overgegaan en in het bezit van den Koning van Engeland geraakt. Ja! Hoogedelgestrenge Heer! op eene schandelijke en lafhartige wijze is de overgave van dat Eiland geschied! Ik herhaal het: geene middelen van verdediging zijn genomen geworden; het inkomen binnen het Fort is den vijand niet belet geworden; de officieren, onderofficieren en Jagers hebben van de hun toebetrouwde wapenen geen gebruik gemaakt; het benoodigde op de nieuwe batterij werd zelfs niet gevonden, ten minsten niet de brandkogels, welke onder het opzicht van den Luitenant van Breningen gemaakt waren en den vijand bij het inzeilen van de haven zeer veel nadeel konde toebrengen, en om den Engelschen bevelhebber het bezit van het eiland nog gemakkelijker te doen geworden, werd de luitenant Balfour door den kommandant Pfeiffer op eigen gezag aan den kommandeerenden officier van het Fort Republiek gezonden, om hetzelve aan den, hem, luitenant, verzellenden Engelschen officier over te geven".

Brisbane heeft volgens Blok ook openlijk uitgesproken, dat hij het bezit van het eiland aan Pfeiffer te danken had, en Blok geeft verslag van het volgende gesprek, later aan boord van de „Arethusa" gevoerd:

Pfeiffer tot Wood: Si nous avions fermés le port, les Anglais auroient-ils pû y entrer? 
Blok: Eh bien! monsieur! Si vous auriez crû necessaire de fermer le port, pourquoi ne l'avez vous pas fait?

Pfeiffer: Ce n'était pas de mon departement.

Blok: Comment ce n'était pas de votre departement, vous qui était commandant et obligé de prendre toutes les mesures possibles d'empecher aux ennemis l'entrée du port?

Blok zei daarop tegen Van Starkenborgh, dat dit geen taal was in den mond van een commandant, en op Pfeiffers vraag: of dit op hem gezegd werd, antwoordde hij: Ja! op U mijnheer! en beduidde hem uitdrukkelijk, dat hij voor zoo'n onwaardigen officier niet meer te spreken was, hem toevoegende: Après mon arrivée en Hollande, monsieur, je serai votre accusateur; vous avez tenu une conduite reprochable et punissable; vous ne meritez pas de servir notre Roi, et quand vous vous aurez justifié, je vous donnerai raison.

Bij deze zelfde gelegenheid bood Brisbane Blok den post van civiel gouverneur van Curaçao aan, maar hij bedankte, ,,mij te binnen brengende, dat ik meer dan dertig jaaren den Lande getrouw gedient hebbe en nooit door hetzelve ondankbaar behandelt was geworden".

Blok laat in het midden, of de andere officieren in het fort hun plicht gedaan hebben, maar zegt wel, dat hij van geen officier dien dag bewijzen van individueele dapperheid heeft gezien.

Ten slotte prijst hij de houding der Engelschen, die niemand der ingezetenen gemolesteerd hebben, en van Brisbane, die zich bij de inneming intrepide gedragen en getoond heeft veel menschelijkheid en deugd te bezitten.

Gelijk gezegd is, wijt De Jonge het slagen van den Engelschen aanval o.m. aan het voeren van de Hollandsche vlag, die als parlementaire vlag placht gebruikt te worden in West-Indië. Nu valt het op, dat allen, die van hun wedervaren op dezen morgen verslag doen, van het voeren van de Hollandsche vlag aan den voortop (met de Engelsche van de gaffel) door de Engelsche schepen spreken, maar geen hunner, land- noch zeeofficier, zegt, dat hij daardoor misleid is of ook maar dientengevolge geaarzeld heeft. Alleen Henning, de bombardier van de Krommelijn, geeft als reden, waarom hij niet op de schepen gevuurd heeft op behalve de order van Schmidt, dat de schepen de parlementaire vlag voerden. $\mathrm{Er}$ is ook in het gouvernementsjournaal van Changuion niets te vinden, dat de bewering van De Jonge bevestigt, dat tevoren reeds door zeeofficieren bij den gouverneur bedenkingen zouden 
zijn gemaakt tegen het gebruik van de Hollandsche vlag als parlementaire vlag onder uiting van de vrees, dat hieruit vroeg of laat nadeelige gevolgen zouden kunnen voorkomen. Trouwens, het was nooit gewoonte, dat die parlementaire schepen zoo maar de haven binnenzeilden; zij bleven voor de haven liggen en de parlementaire officier ging met een sloep aan wal, na daartoe vergunning te hebben bekomen (zie hiervóór het op 22 December 1806 voorgevallene).

Changuion maakt van deze zaak even melding, als hij in zijn relaas op het daaruit reeds meegedeelde volgen laat, dat hij niet begrijpt waarom niet reeds een groot half uur eerder alarm geschoten is, en zegt dan: ,Men zegt dat men in vertwijfeling gebragt is, omdat de schepen onder Parlementaire Vlag afkwamen, en dat ook door de betrokkene lugt en het regenachtig weer de scheepen niet dan een klein half uur, voordat zij binnen zeilden en de Haven forceerden, gezien zijn, kunnende men toen door de schemering volstrekt niet onderkennen welke schepen het waren". Velen hebben echter verzekerd, dat zij weinig na half vijf uur de afkomende schepen reeds duidelijk hebben onderscheiden.

Changuion heeft over het uitzicht op dien nieuwjaarsmorgen ook een gesprek gehad met den Engelschen kapitein Lydiard, die op het gouvernementshuis logeerde. Den 2den Januari 1807 vóór half zes 's morgens vroeg hij den Engelschen kapitein, of het den vorigen ochtend een kwartier of half uur vroeger ook zoo licht was als dien 2 den, toen de maan helder scheen, en ontving ten antwoord, dat het den vorigen ochtend op denzelfden tijd zeer betrokken en regenachtig was geweest, en dat hij, Lydiard, dacht, ,,dat men de scheepen naauwelijks een half uur, voordat zij binnen waren gezeild, duidelijk had kunnen onderscheiden".

Aan het einde van zijn relaas gaf de gouverneur nog een overzicht van het verloop van den aanval zelf, zooals hem dat was gerapporteerd.

De schepen waren dan onder parlementaire vlag afgekomen: voorop de ",Arethusa" met 3 gewapende sloepen aan elke zijde, waarvan er reeds geland zouden zijn tusschen de Krommelijn en de beide Waterforten of in dien omtrek, vóór het schip de haven binnenzeilde. De bemanning der sloepen was met stormladders gegaan naar het fort en waar de vlaggestok staat, en had de muren beklommen na het eerste vuren der binnengezeilde schepen, toen ook de batterij voor het gouvernementshuis door den Engelschen commandant beklommen was. De parlementaire officier zou bij 
het kerkhof aangetroffen zijn, waaruit Changuion afleidt, dat deze met de eerste chaloup is geland.

Bij de Krommelijn is niet gevuurd; geen wonder, schrijft Changuion, want er waren nog geen alarmschoten gedaan en de batterijen dus niet genoegzaam bezet ${ }^{\mathbf{1}}$ ). Het eerste schip zeilde de haven binnen 1 of 2 minuten na de alarmschoten, gevolgd door de andere schepen. Toen werd er van de batterij vóór de hoofdfortres gevuurd door de weinige manschappen, die zich in aller ijl derwaarts begeven hadden, en de „Kenau Hasselaar” en „Suriname" deden ook eenige schoten, doch dat duurde niet lang, want de ,Arethusa", tusschen beide schepen door gezeild zijnde, liet voor het huis van Primet het anker vallen. De Engelsche schepen zetten dadelijk volk aan wal, dat de burger-batterijen ijlings bezette.

Een der andere fregatten ging aan de eene zijde der „Kenau Hasselaar" liggen, het derde aan de andere zijde; de beide Hollandsche schepen werden geënterd en moesten zich overgeven. Het vierde Engelsche fregat ging vóór het gouvernementshuis liggen en deed het schroot en kartetsvuur der batterijen op de hoofdfortres zwijgen. Die batterijen werden ijlings verlaten, waarna de Engelsche commandant geen moeite had zich met zijn volk daarvan meester te maken en bezit van het hoofdfort en van het gouvernementshuis te nemen. ,Zoo vond ik de zaken”, aldus Changuion, ,,toen ik de hoofdfortres binnenkwam een groot $1 / 2$ uur à $3 / 4$ uur nadat ik gesignaleerd was en de alarmschoten gedaan waren".

Het is niet onwaarschijnlijk, dat deze weergave der feiten, door den gouverneur aan de hand van mondelinge ooggetuigen-verklaringen opgemaakt, de beste samenvatting van de krijgsgebeurtenissen is. Zij laat weinig reden tot roemen over.

Alles was den vijand mee, vervolgt Changuion: wind, stroom, betrokken lucht, regenachtig weer, ,,verzeld van een favorable brise”. Hij brengt hulde aan de bemanning van de „Kenau Hasselaar", voorzoover niet laf overboord gesprongen. Evertsz is gesneuveld, ,terwijl hij zelfs de stukken derigeerde”. Slotendijck heeft door zijn koelbloedigheid en onverschrokken bedaardheid de eer der Hollandsche vlag gered. Onze vlag is door de Engelschen neergehaald. Ook aan de bemanning van de „Suriname" brengt hij hulde.

1) Dit wordt gelogenstraft door de reeds genoemde verklaring van den bombardier Henning. 
De Engelschen hebben meer volk verloren dan wij. Zij hebben hun dooden 's nachts met chaloupen buiten de haven gebracht en in zee geworpen. In het hospitaal zijn veel gekwetsten. Changuion vermeldt dit niet als een bewijs van onze bravoure maar om aan te toonen welk een slachting waarschijnlijk onder den vijand zou zijn aangericht, als tijdig alarm gemaakt was. „, , welk een roemrijke dag had de Eerste Jan. voor ons kunnen zijn, indien men slegts 20 a 30 minuten vroeger bij de hand ware geweest!!! roept de gouverneur, tot zoo ver gekomen, uit.

Uitvoerig geeft hij vervolgens de redenen op, die hem ertoe gebracht hebben het fort Republiek over te geven:

1) de bezetting van stad, haven en hoofdfort door de Engelschen. Het fort Republiek kon niet meer op de Engelsche schepen vuren zonder onze bemanningen, die krijgsgevangen op de „Kenau Hasselaar" en „Suriname” waren, aan een gewissen dood bloot te stellen en met weinig kans de vijandelijke schepen ernstig te beschadigen;

2) het garnizoen had de wapens reeds neergelegd en was krijgsgevangen;

3) de gewapende burgermacht was ,gebandeert”, en geen dienst ervan te verwachten;

4) verdediging van fort Republiek zou stad en hoofdfortres aan het vuur van de 4 fregatten blootstellen, die daardoor en door onze eigen batterijen in weinige minuten tot een puinhoop zouden geschoten zijn zonder eenig middel van defensie van die zijde; alles zou dus in een weerloos moordtooneel herschapen zijn;

5) de vijandelijke schepen hadden zich in de haven voor het vuur van fort Republiek kunnen dekken;

6) er kon geen order naar het fort gezonden worden om weer met vuren te beginnen;

7) ook konden de bezettingen der buitenposten niet verzameld worden voor een aanval op den vijand; bovendien waren die onvoldoende bewapend.

Uit de aanteekeningen en brieven van Changuion is het bekend, hoe het verder gegaan is, tot gouverneur en krijgsmacht het eiland verlieten.

De krijgsgevangenen werden gebracht aan boord van de "Anson" en de Engelschen namen hun intrek in de kazerne en kwartieren.

De oud-fiskaal Van Starckenborgh kwam tegen den middag op het gouvernementshuis en ging van daar met den secretaris Wen- 
ckebach namens den gouverneur de weduwe van den commandant Evertsz deelneming betuigen. In den middag ging Changuion er ook zelf nog heen met den secretaris. De begrafenis den volgenden ochtend, waarbij Hollandsche en Engelsche officieren het lijk volgden, kon de gouverneur niet bijwonen.

Van Hollandsche zijde stelde men zich op het standpunt, dat de capitulatievoorwaarden van preliminairen aard waren en nog uitgewerkt moesten worden. Daartoe zetten zich Changuion en Wenckebach aanstonds na afloop van den maaltijd, die kapitein Lydiard als commandeerend officier met zijn adjudant gebruikt had bij den gouverneur, die voor een uitnoodiging bij Brisbane had bedankt.

De Engelsche opperbevelhebber wilde echter niets van verandering in de capitulatievoorwaarden weten. Slechts stond hij er met veel nadruk op, dat in art. 5, dat den vreemdelingen eerbiediging van hun persoon en eigendom waarborgde, zou worden opgenomen, dat dit alleen voor neutrale vreemdelingen gold, daar aan onderdanen van den Engelschen vijandige natiën, behalve aan de Hollanders, hun eigendom niet kon gewaarborgd worden. En art. 6 werd naast art. 5 overbodig geacht. Toen het op teekenen aankwam, werd aan art. 5 ook nog toegevoegd, dat de ingezetenen den eed van trouw aan den Engelschen moesten doen om van het daar verleende voorrecht te kunnen genieten.

Changuion gaf toe, ofschoon hij wel bezwaar had tegen deze ingrijpende wijzigingen. Verzet zou hem trouwens niet gebaat hebben.

Ook den 2den Januari weigerde de gouverneur aan te zitten aan een maaltijd bij Brisbane, maar den volgenden dag was deze bij hem te gast met de Engelsche kapiteins, Van Starckenborgh, Blok, Wenckebach en 't Hoen.

Den 4den Januari vaardigde Changuion een soort proclamatie aan de bevolking uit, die den volgenden dag werd afgekondigd. Daarin werden de artikelen 4 en 5 van de capitulatie meegedeeld. $Z_{\mathrm{ij}}$ eindigde aldus: „Ik begeef mij naar mijn Vaderland om Rekenschap te geven van de minste daad zelfs, op dit Eiland bedreven - de Dagen, die wij hier doorgebragt hebben, en de gevaaren, die gij met ons gedeeld hebt, zullen bij ons in steeds duurend aandenken blijven. - Rust en Eendragt blijve uw bestendig Erfdeel; De koophandel, de bron van uw bestaan bloeie".

Onder degenen, die niet bereid waren onder den Engelschen koning te blijven dienen, behoorden met Changuion, Blok, Wenckebach, de ontvanger De Veer, de boekhouder-generaal Van 
Eck, de vendumeester 't Hoen, de waagmeester Evertsz, de equipage-, haven- en rooimeester Pletz. Van Starckenborgh, wien de Engelschen aangeboden hadden weer fiskaal te worden, vroeg des gouverneurs raad. Changuion antwoordde, dat hierin ieder naar overtuiging moest handelen, maar dat het „,misschien wenschelijk" en ten nutte der ingezetenen zou zijn, als hij bleef. Tot dit laatste besloot Van Starckenborgh.

Zondag den 4den pakte de gouverneur zijn papieren en die van het gouvernement, en ruimde hij zijn ambtswoning in voor kapitein Bolton, die er den volgenden dag ging wonen als opvolger van Lydiard, die met de „Anson” dien dag vertrok om de Hollandsche krijgsgevangenen over te brengen. Changuion nam zijn intrek in een gehuurd huis in de Breedestraat van Otrabanda; van de landsslaven mocht hij 1 jongen en 2 meiden tot zijn bediening meenemen.

6 of 8 Januari had de eedsaflegging van ambtenaren en burgers plaats; het gelukte Changuion niet het formulier hiervan machtig te worden.

Op 9 Januari maakte Brisbane plotseling bekend, dat hij dien dag om 12 uur wilde vertrekken. Changuion liet den nieuwen fiskaal om uitstel vragen, maar kreeg van dezen schriftelijk bericht, dat hij met moeite uitstel tot twee uur had weten te bedingen. Zelf kon Van Starckenborch, aan wien Changuion tot een gedachtenis het werk van den abt Raynal over de beide. Indiën gegeven had, niet meer komen ,zijnde zoo gefatiqueerd, dat hij vreesde ziek te zullen worden".

„Ik ben dan vertrokken”, verzucht Changuion, ,,zonder dat de Fiscaal Van Starckenborgh mij goede reis is komen wenschen of afscheid van mij genomen heeft... De Ontvanger De Veer heeft mij sedert de komst der Engelschen niet eenmaal bezocht". Wel kwamen afscheid nemen Th. en Chr. Jutting ${ }^{1}$ ), de advocaat Römer ${ }^{2}$ ), de burgerofficier Ellis en de weesmeester Rojer ${ }^{3}$ ).

Toen de „Arethusa” tusschen 1 en 2 uur vertrok met de ,,Kenau Hasselaar", ,Suriname” en „Vliegende Visch" als prijzen, waren met Changuion aan boord Sloterdijck, Blok met zijn stief-

1) Christian Willem Jutting koopman, gehuwd met Anna Sophia Jutting.

2) Mr. Constantinus Petrus Römer was in 1797 gouvernementssecretaris ad interim geweest. Hij was gehuwd met Cornelia Willemina van der Linden.

3) Waarschijnlijk Frans Royer, die van 1816-1818 nog als weesmeester voorkomt en tot 1824 als ongegradueerd lid van dien raad van civiele en crimineele Justitie. 
dochter ${ }^{\mathbf{1}}$ ), Wenckebach, de chirurgijn-majoor der jagers $\mathrm{P}$. Maes, De Quartel, de luitenants Rabainne en Hendriks, de schrijvers Platz en Sauvage en de chirurgijn-majoor der marine Tappert.

,Wat er wijders bij dit verlaten van Curaçao in mij omging", aldus besluit Changuion zijn relaas, ,,kan men ligt beseffen, en dit gevoel zou nog des te sterker geweest zijn, indien ik geweten had, welk noodlot mijn schoonzoon en andere Negotianten en Ingezetenen over het hoofd hing. Bij het uitzeilen der Haven werden er 21 saluutschoten gedaan!"

11 Januari was de „Anson” te Port Royal op Jamaica aangekomen en 4 dagen later kwam de „Arethusa”. Van Brisbane's toezegging, dat de Engelsche admiraal daar, Dacres, voor behoorlijken overtocht naar Holland zou zorgen, kwam niet veel te recht. Wel huurde hij 2 brikken voor het garnizoen, waarvan er een verrot was, zoodat vele officieren weigerden aan boord te gaan, vergunning kregen over Noord Amerika te reizen, en de bemanning op het andere opgehoopt werd. Changuion, Wenckebach en Slotendijck verkozen met een particuliere gelegenheid over Charlestown in Zuid-Carolina te gaan. Het garnizoen, voor zoover het niet te Kingston in Engelschen dienst was overgegaan, vertrok 7 of 8 Februari van Jamaica. De volgepropte brik moest wegens gebrek aan water en hout eerst nog in Charlestown binnenloopen en kwam 8 Juni te Helvoet binnen.

11 April was Changuion nog te Charlestown. Sedert een week was hij aan boord van de „Belfast”, kapitein Inglish, die al uitgezeild was geweest, maar op de bank gestooten en tot herstelling der schade terug gekeerd. De ,braave” Slotendijck en de ,,verdienstelijke" Wenckebach waren reeds eerder vertrokken. Aldus schreef Changuion 13 Maart en 11 April 1807 aan den minister van Koophandel en Koloniën.

Op den dag, waarop de brik met het garnizoen te Helvoet binnenliep, kon Changuion zich eindelijk bij Den Briel laten afzetten, en twee dagen later berichtte hij den minister, dat hij 9 Juni 1807 aangekomen was en zijn intrek genomen had in het logement het „Groot Keijzershof” te 's Gravenhage „,na vijf maanden tegenspoeds en disfortuyns". Hij vroeg een onderzoek van zijn gedrag en openlijke rechtvaardiging, als blijkt, gelijk hij vertrouwde, ,,dat

\footnotetext{
1) Blok was weduwnaar. Zijn tweede echtgenoote Johanna Cornelia Vaillant ( $\dagger 1803$ ) had uit haar eerste huwelijk met mr. P. Buyskes een dochter Margaretha Elisabeth Buyskes, die bij haar stiefvader is gebleven.
} 
het noodlot aan deeze Colonie overkomen aan mij niet te wijten is".

Euwens deelt, gelijk gezegd, (blz. 261 e.v.) mee, dat op last van koning Lodewijk Napoleon Changuion, Pfeiffer, Van Nes en Slotendijck 12 Augustus 1807 door den minister van Marine Verhuell in de generaliteits-provoost werden gevangen gezet, en de eerste twee door het Hoog militair gerechtshof tot de straf met den kogel zijn veroordeeld, terwijl Van Nes en Slotendijck werden vrijgesproken, daar zij ,,wegens het verlies hunner schepen gerechtvaardigd en van alle schuld wegens wandevoir of lafhartigheid vrij gekend waren".

Dit nu is niet juist. Het is op zichzelf al niet waarschijnlijk, dat de minister van Marine met het geval iets te maken had, voor zooveel Changuion en Pfeiffer betreft, want eerst in het volgend jaar werd ,Koloniën” met „Marine” vereenigd. De gewezen gouverneur schrijft dan ook in zijn memorie aan den Souvereinen Vorst (blz. 24), dat hun beider aanhouding op last van den minister van Koophandel en Koloniën geschiedde. Niet voor het Hoog militair gerechtshof maar voor de Hooge militaire vierschaar hebben zij terechtgestaan.

19 December 1807 werden de ,informatiën” (het vooronderzoek) gesloten, en vier dagen later werd Changuion aangezegd, ,,dat de Fiscaal geadmitteerd was, om op Convictie Eisch tegen hem te doen". 8 Januari 1808 werd de straf met den kogel tegen hem geëischt. In Februari diende Chauguion zijn memorie van defensie in (Memorie, blz. 25).

Volgens de Secrete notulen van de Hooge Militaire Vierschaar (bundel 1 Jan. 1807-ultimo Februari 1811. Algemeen rijksarchief H. M. V. 33) praeadviseerde in de vergadering van 18 Maart 1808 het lid Costerus tot toewijzing van eisch en conclusie van den advocaat-fiskaal, en drie dagen later viel de beslissing. Negen leden (Van Raders, Van Boecop, Moorrees, Van Woensel, Broux, Pijman, Droghorn, Bijll en Queijssen) gingen met Costerus mee. Slechts twee leden waren van een ander gevoelen. Haringman meende, dat volstaan kon worden met cassatie (ontslag) uit 's konings dienst en inhabiel (onbekwaam) verklaring om den koning ooit weer als militair te dienen, twee jaren confinement (opsluiting) en veroordeeling in de kosten. De president wilde behalve cassatie en inhabielverklaring een jaar detentie in het Provoosthuis met aftrek van het reeds ondergane arrest.

De meerderheid had dus beslist, zooals de voorzitter vaststelde, 
,,dat de gedetineerde bij sententie van deeze Hooge Militaire Vierschaar zal worden gecondemneert, om met den kogel te worden gestraft, dat er de dood op volgt".

In de vergadering van 29 Maart werd het vonnis vastgesteld, waarna het aan den minister van Justitie en Politie werd toegezonden om aan den koning ter approbatie te worden voorgedragen.

Eerst vier maanden later was de beschikking van den koning bekend. Changuion schrijft in zijn memorie (blz. 26), dat hij slechts met moeite er toe is kunnen overgaan gratie te vragen. $\mathrm{Bij}$ decreet van 6 Juli 1808 werd hem verleend ,remissie van alle straf, waartoe hij is veroordeeld, mits betalende de kosten en met dien verstande dat hij nimmer eenige politiecque of militaire charge zal kunnen bekleeden". De vierschaar besloot daarop den minister terugzending te vragen van de sententie, ,,ten einde daarvan, met ende benevens het hiervooren vermelde Decreet behoorlijke pronuntiatie zouden kunnen worden gedaan".

Intusschen was de beschikking van den koning den veroordeelde, althans zijn verdediger, bekend geworden. Immers in de vergadering van 20 Juli deelde de voorzitter van de vierschaar mee, dat de procureur Bollard zich bij hem had vervoegd voor zijn meester Changuion met de mededeeling, dat hij had kennis genomen van het ,favorabel Decreet” van den koning, en met verzoek om hem, ,,zoodra mogelijk nadat hij aan den inhoud van hetzelve Decreet zoude hebben voldaan, het effect daarvan te doen genieten”. Besloten werd te antwoorden: ,de Vierschaar is nog delibereerende maar zal al het mogelijke daartoe doen".

De laatste aanteekening in de secreete notulen over deze zaak is van 22 Juli 1808, en luidt, dat is gedisponeerd ,,als in 't gewone register van heden staat aangetekend". Die aanteekening geeft geen opheldering; waarschijnlijk is op dien dag het vonnis uitgesproken.

De sententie zelf is te vinden in het desbetreffende boek der sententiën van de Hooge militaire vierschaar op het Algemeen rijksarchief en is zeer uitvoerig. Het is van belang daaruit een en ander vast te leggen.

In zijn memorie (blz. 27 tot 29) zegt Changuion, dat hij wegens „,militaire fouten" is veroordeeld, volgens het Reglement van discipline van 1798, terwijl hij geen militair was en dit reglement zwijgt van ,,de Colonien en derzelver Opperhoofden, en ook hem niet tot een Rigtsnoer van zijn gedrag is medegegeven geworden". In de sententie heb ik echter dit reglement niet vermeld gevonden. 
Wel wordt daarin uitdrukkelijk naar aanleiding van dit, ook daar gevoerd, verweer verwezen naar des gouverneurs instructie, volgens welke Changuion het hoogste gezag in politieke en militaire zaken had en het opperbestuur over de militie. Verder wordt aangehaald, dat zijn instructie den gouverneur voorschreef een grooten krijgsraad van de hooge militaire officieren en politieke ambtenaren bijeen te roepen in geval de eilanden met een aanval van buiten bedreigd of dadelijk geattaqueerd of beroerd zouden worden ter beraming van middelen tot defensie, en ten slotte dat hem bijzondere zorg voor de verdediging van fort en haven en van de batterijen, met name van den berg Scharlo, was opgedragen.

Op vier punten heeft de vierschaar des gouverneurs beleid gewraakt:

1) had hij na 22 December 1806 geen blijkbare afdoende maatregelen hoegenaamd in het werk gesteld om het eiland tegen allen vijandelijken aanval zooveel mogelijk te verzekeren;

2) had hij niet volgens zijn instructie na de sommatie van 22 December een grooten krijgsraad gehouden; ${ }^{1}$ )

3) was hij naar buiten gegaan;

4) was hij binnen het fort gegaan, wetende of kunnende vermoeden, dat dit door den vijand genomen was, waarmee hij zich in handen van den vijand gaf, waardoor alle middelen om nog iets tot het verdrijven van den vijand te kunnen doen vervielen; als krijgsgevangene had hij toch nog vergaderd met krijgsgevangen officieren over de overgave, orders tot overgave uitgevaardigd, ook voor nog niet geoccupeerde posten ${ }^{2}$ );

1) In zijn memorie (blz. 14) zegt Changuion, dat hij dit niet gedaan heeft, omdat er orders waren, die op het eerste sein konden worden uitgevoerd, en nieuwe orders eerst zouden kunnen gegeven worden, als men wist waar de aanval plaats vond en hoe groot de macht was, waarmee werd aangevallen, en ook omdat de ondervinding geleerd had, dat het om meer dan een reden niet raadzaam was buiten volstrekte noodzakelijkheid dezen krijgsraad bijeen te roepen. Hij verklaarde ook zich bevoegd te hebben geacht van zijn instructie af te wijken, als hij dit tot zijn verantwoording beter vond.

2) Dit herinnert levendig aan hetgeen bij den overval van Urbina in 1929 plaats vond. Zie De W e s t-I n d i s c h e G i d s $12 \mathrm{de}$ jg., blz. $133 / 4$. In zijn memorie (blz. 19) verklaart Changuion, dat hij niet naar fort Republiek maar naar het hoofdfort is gegaan, door mee te deelen, dat hij meende, dat de Engelschen in het hoofdfort nog niet de baas waren, en omdat fort Republiek reeds met vuren had opgehouden. De door Changuion bedongen ,,honorabele capitulatie" wil de Vierschaar hem blijkbaar niet als verdienste aanrekenen.

West-Indische Gids XXV 
Uitdrukkelijk wordt in de sententie ook nog gesproken van het niet-sluiten van de haven.

De vierschaar qualificeert de feiten, die zij Changuion verwijt, als ,verregaand plichtverzuim en wandevoir, mitsgaders.... zoodanige gedragingen, als welke in eenen gouverneur en opperbevelhebber, aan wien de defensie eener buitenlandsche bezittinge ware toevertrouwd, niet konden worden geleden, maar als militaire misdaden op het rigoureust behoorden te worden gestraft.

De feiten, waarvoor Changuion veroordeeld is, staan vast. Over het antwoord op de vraag, of de straf evenredig is met de schuld van den gouverneur aan de overgave, kan men van meening verschillen, zooals ook in de vierschaar geen eenstemmigheid heeft bestaan. En zulks te meer, omdat het lang niet zeker is, dat, als wèl groote krijgsraad gehouden was na de sommatie van 22 December 1806, en de gouverneur eens niet naar buiten was gegaan, het verloop anders zou geweest zijn; de sententie tegen Pfeiffer wijst op zooveel tekortkomingen van die zijde, dat hierover eigenlijk weinig twijfel kan bestaan.

Het verzoek van den veroordeelde om gratie is door den koning gesteld in handen van het Hoog Nationaal geregtshof van het koningrijk Holland. Het advies van 27 Juni 1808, op het Algemeen rijksarchief aanwezig (Nat. Geregtshof no. 27), strekte om niet de gevraagde abolitie ${ }^{1}$ ) te verleenen, ,,als... in deesen zoo wegens den Staat der zake als ook alles wederom in verband en te zaam beschouwd minder gepast en oirbaar", maar wel remissie van alle straffen, mits de kosten betalende.

Voor dit advies werden 9 gronden aangevoerd, nl.

$1^{\circ}$. de uit het proces gebleken oprechtheid en waarheidsliefde van Changuion, met vermijding van alles, wat anderen zou kunnen benadeelen of in het minst bezwaren ${ }^{2}$ ), waaruit het hof de gevolgtrekking maakt, dat ook zijn verzekeringen van goede trouw en van het beste oogmerk om aan eed en plicht in zijn post naar vermogen te hebben getracht te beantwoorden overeenkomstig de waarheid zijn;

1) Onder abolitie verstaat men thans het opgeven van het recht tot strafvervolging of tot voortzetting van een aangevangen vervolging. Het is mij niet mogen gelukken te vinden wat daaronder destijds verstaan werd. In ieder geval is het een vorm van gratie.

2) Dit is wel te gunstig voorgesteld. Uit het gratieverzoek haalt het Hoog nationaal gerechtshof zelf aan: ,dat in allen gevalle het verzuim meerder aan den militairen commandant zoude moeten geïmputeerd worden, die door hem aldaar was agtergelaten en beloofd had voor alles te zullen zorgen"'. 
$2^{\circ}$. de verklaring van de vierschaar, dat geen grond is gevonden om te veronderstellen of te vermoeden, dat de gouverneur verraderlijke oogmerken of slinksche bedoelingen zou hebben gekoesterd, om willens en wetens de verdediging van het eiland te benadeelen of te ,,praejudicieren";

$3^{\circ}$. dat geen persoonlijke lafhartigheid hem is verweten;

$4^{\circ}$. zijn vorig gedrag als gouverneur;

$5^{\circ}$. ten aanzien van het tusschen 22 December 1806 en 1 Januari 1807 voorgevallene, door de vierschaar als verregaand plichtsverzuim en wandevoir ex officio geoordeeld en als militaire misdrijven, van de straffen waarop hem niet kan bevrijden, dat hij uit onkunde in het militaire zou hebben gehandeld: het afslaan der sommatie van 22 December 1806, de door den gouverneur aan de officieren aanbevolen waakzaamheid, zijn ,,zorgende bekommering"' op 31 December, zoolang de vijandelijke brik in het gezicht was, en zijn gesprek met Pfeiffer, en ten slotte zijn spoed om op 1 Januari zich naar de hoofdfortres te begeven;

$6^{\circ}$. dat hij geen militair van professie was, en daarom dat hij zich op de goede trouw en stellige beloften van plichtsbetrachting van anderen verlaten heeft, hem minder zwaar is aan te rekenen;

$7^{\circ}$. dat voor het gaan naar buiten verzachtende omstandigheden zijn aan te voeren uit hetgeen daaraan voorafging, en dat, als ieder zijn plicht had gedaan, de gouverneur daarvoor niet in rechten zou betrokken zijn;

$8^{\circ}$. dat door een onvoorziene samenloop van omstandigheden de verovering van het eiland is mogelijk geworden (hierbij wordt - wat vreemd - gewezen op de zwakke lichaamsgesteldheid van den gouverneur, welke hem reeds in 1805 genoopt had „op zijne repatriering te insisteren" 1 ), en op zijn overigen dienst, waarvan het hof zegt, dat het heeft mogen nagaan, ,dat zoo veel in hem was en zijne kunde en doorzigt toeliet, de beste wil om voor zijn vaderland dienstbaar te zijn doorstrale");

$9^{\circ}$. de reeds ondergane detentie, de moeilijke terugreis, en afwijzing van het aanbod om zijn post te blijven bekleeden.

Uit het advies blijkt, dat ook de vierschaar op het verzoek om

1) Wanneer Changuion ontslag heeft gevraagd, heb ik niet in officieele stukken gevonden; wel dat hij meer dan eens verlof vroeg, o.a. 5 April 1816 ,,om zoodra de vreede geslooten is en hier officieel bekend worden zal, behoudens qualiteit etc. een keer naar Holland te mogen doen". Bij koninklijk besluit van $19 \mathrm{Jan} .1807$ is hem intusschen ontslag verleend met benoeming van den luitenant-generaal Van Geuricke tot zijn opvolger. 
gratie nog is gehoord en erop gewezen heeft, dat zij aanneemt, dat Changuion ook op 1 Januari 1807, als in 1805, wenschte het eiland voor den staat en den koning te behouden, en dat zijn plichtverzuim niet zonder grond zou kunnen worden toegeschreven aan zijn ,,beperkt doorzigt, onkunde en onbedrevenheid in militaire zaken, waardoor hij speciaal in tijd van oorlog voor den gewigtigen post aan hem opgedragen minder dan een militair van professie berekend was".

Aan het advies gaat vooraf een samenvatting van het gratieverzoek. Dit komt in hoofdzaak neer op het betoog, dat Changuion zich veel meer als politiek dan als militair persoon beschouwd heeft. Toch bevat het ook een betuiging van leedwezen over het niet-beter-sluiten van de haven, het niet-houden van een grooten krijgsraad op 22 of 23 December 1806, het naar-buiten-gaan op 31 December en het niet-herhalen van de gegeven orders. Changuion betoogt verder, dat zijn aanwezigheid op de hoofdfortres waarschijnlijk niet zou hebben weggenomen de oorzaken, die tot het slagen van den aanval hebben geleid, en uitdrukkelijk noemt hij hier het wegloopen van de kanonniers op de buitenpost de Crommelijn ${ }^{1}$ ).

De Souvereine Vorst heeft bij resolutie van 23 November 1814 goedgevonden al hetgeen bij de sententie van de Hooge militaire vierschaar aan Changuion , tot delict is geïmperteerd, te aboleren en te vernietigen,... wordende... Pierre Jean Changuion, tot zijnen goeden naam en faam, en in den staat, waarin hij was vóór de pronuntiatie van dezelve, hersteld en gerestitueerd".

Dit besluit is genomen ,GGehoord den eersten president van het hoog geregtshof der Vereenigde Nederlanden", mr. C. F. van Maanen, die als minister van Justitie geadviseerd had op het verzoek van Changuion om abolitie of remissie van straf, waarop koning Lodewijk Napoleon gunstig beschikt had. Het is jammer, dat dit rapport mondeling is uitgebracht, waardoor de gronden, die tot 's Konings beslissing hebben geleid, verborgen blijven.

$\mathrm{Na}$ de gunstige beschikking van Willem I is Changuion eerst benoemd tot griffier van de rechtbank te Goes en later in rechterlijke betrekking in Suriname geplaatst, waar de in 1809 met zijne dochter gehuwde P. Balfour van Burleigh als luitenant-kolonel bij de jagers garnizoenscommandant was geworden. Als secretaris van het hof van Justitie overleed Changuion in 1820 te Paramaribo.

1) Mij uit niets gebleken en in de gedingstukken niet besproken. 
Kapitein Pfeiffer is niet ter dood veroordeeld. Had Changuion tot het einde zijn onschuld volgehouden, Pfeiffer heeft voor commissarissen der vierschaar ten slotte bekend zijn plicht verzaakt te hebben en zich ter verontschuldiging op zijn ,,confusie" beroepen. De advocaat-fiskaal had tegen hem dezelfde straf als tegen Changuion geëischt. De secreete notulen van 22 Maart 1808 vermelden, dat 5 leden voor toewijzing van dezen eisch stemden en 7 voor cassatie uit 's konings militairen dienst met inhabielverklaring om den koning ooit weder als militair te dienen. Daartoe was dus besloten. Vier van deze leden wilden daarbij de straf van detentie zien opgelegd, maar over den duur daarvan waren zij het niet eens: één lid was voor 2 jaar, twee waren voor 1 jaar, één voor 6 maanden. De president concludeerde, dat dus tot 1 jaar detentie besloten was.

Deze straf is 30 December 1808 uitgesproken en van eenige gratie, door den koning verleend, blijkt uit de secreete notulen niets.

Wat de feiten betreft neemt de vierschaar aan, dat om kwart over vijven de commandant in zijn woning door een vice-sergeant van de hoofdwacht in de hoofdfortres is gewaarschuwd, dat er een schot van Caracasbaai was gevallen; daarna had het fort Krommelijn gerapporteerd, dat een vaartuig - en vermoedelijk meer - zich bevond tusschen Caracas- en Cornetsbaai. De commandant had zich naar de batterij en het kruitmagazijn begeven en de vaartuigen gezien. Eerst om kwart vóór zessen had hij het seinschot voor den gouverneur laten geven.

Door deze inactiviteit, zegt de Vierschaar, konden de alarmschoten geen nuttig effect meer hebben. Te laat zijn de orders tot het sluiten van de hoofdfortres gegeven.

Aan deze feiten is te wijten de confusie op de batterijen en in het hoofdfort.

Bovendien waren de batterijen niet in orde en niet van het noodige voorzien. Daardoor kon de vijand met nog geen 300 man de hoofdfortres bemachtigen.

Krijgsgevangene zijnde, had Pfeiffer den korporaal Bosch naar fort Republiek gezonden met het bevel om niet meer te vuren, en den luitenant Balfour van Burleigh meegegeven aan het Engelsche detachement, dat dit fort ging opeischen.

Voor deze feiten, zijnde desobedientie en wandevoir, al hetwelk van een alleszins nadeelig gevolg geweest is voor de verdediging van een buitenlandsche bezitting, werd Pfeiffer veroordeeld.

De verdere levensloop van Pfeiffer heb ik niet kunnen volgen. 
Van eenige vervolging tegen Van Nes en Slotendijck blijkt uit de Sententiën van de Hooge militaire vierschaar niets. De Jonge noemt echter uitdrukkelijk den datum dezer sententiën, 11 Maart 1808. Deze datum is in elk geval niet juist.

In de stukken van de Hooge militaire vierschaar vond ik het volgende.

Behalve tegen Changuion en Pfeiffer is een vervolging voorgenomen tegen Schmidt, Krapf, Van Breeniegen, Hendriks, Siecker, Boyé en ook tegen de twee genoemde zeeofficieren. Sommigen hunner, als Van Nes en Slotendijck kregen in 's Gravenhage stadsarrest, Boyé eerst zelfs kamerarrest; op Van Breeniegen en Hendriks werd ,,een wakend oog"' gehouden. Den voorlaatste is door den advocaat-fiskaal verweten ,,verregaand wandevoir en lafhartigheid", omdat hij niet gezorgd had, dat de lonten goed en in orde waren en de ammunitiekist van de batterij de Waag geopend kon worden, waardoor het seinschot en de alarmschoten vertraagd waren, - omdat hij de nieuwe batterij onder het gevecht met den vijand had verlaten en zich in vriendschappelijk gesprek begeven had met den officier der vijandelijke troepen, die de batterij beklommen en hem naar den commandant had gevraagd, en omdat hij, in de macht van den vijand zijnde, evenals Pfeiffer, dezen aangeraden had een boodschap naar fortRepubliek te zenden om het vuren te staken.

Aan Schmidt is verweten, dat het aan zijn schuld zou te wijten zijn, dat de batterij Krommelijn niet gevuurd had, daar hij 10 October 1805 buiten den gouverneur om een order had uitgevaardigd, dat van daar niet mocht gevuurd worden, vóór daartoe van de nieuwe batterijen een seinschot was gedaan.

Op 25 Maart 1808 stelde de advocaat-fiskaal aan de Hooge militaire vierschaar ten aanzien van Van Nes en Slotendijck voor, dat zij zouden worden ,,vrijgekend... van alle schuld uit hoofde van wandevoir of lafhartigheid"'. Blijkbaar is aldus beslist. Stukken over hen en de andere genoemden heb ik verder niet gevonden.

Dat deze aanval had kunnen worden afgeslagen, kan niet aan redelijke twijfel onderhevig zijn. Daarvoor was zij te gewaagd. Er is ten minste een uur verloopen tusschen de waarneming der schepen en het binnenzeilen der schepen. Meer dan één vraag blijft open. Waarom is fort Beekenburgh niet blijven vuren op de Engelsche schepen? Wat kan de redelijke zin geweest zijn van de order van Schmidt, die dẹ batterij Krommelijn verbood te vuren? 


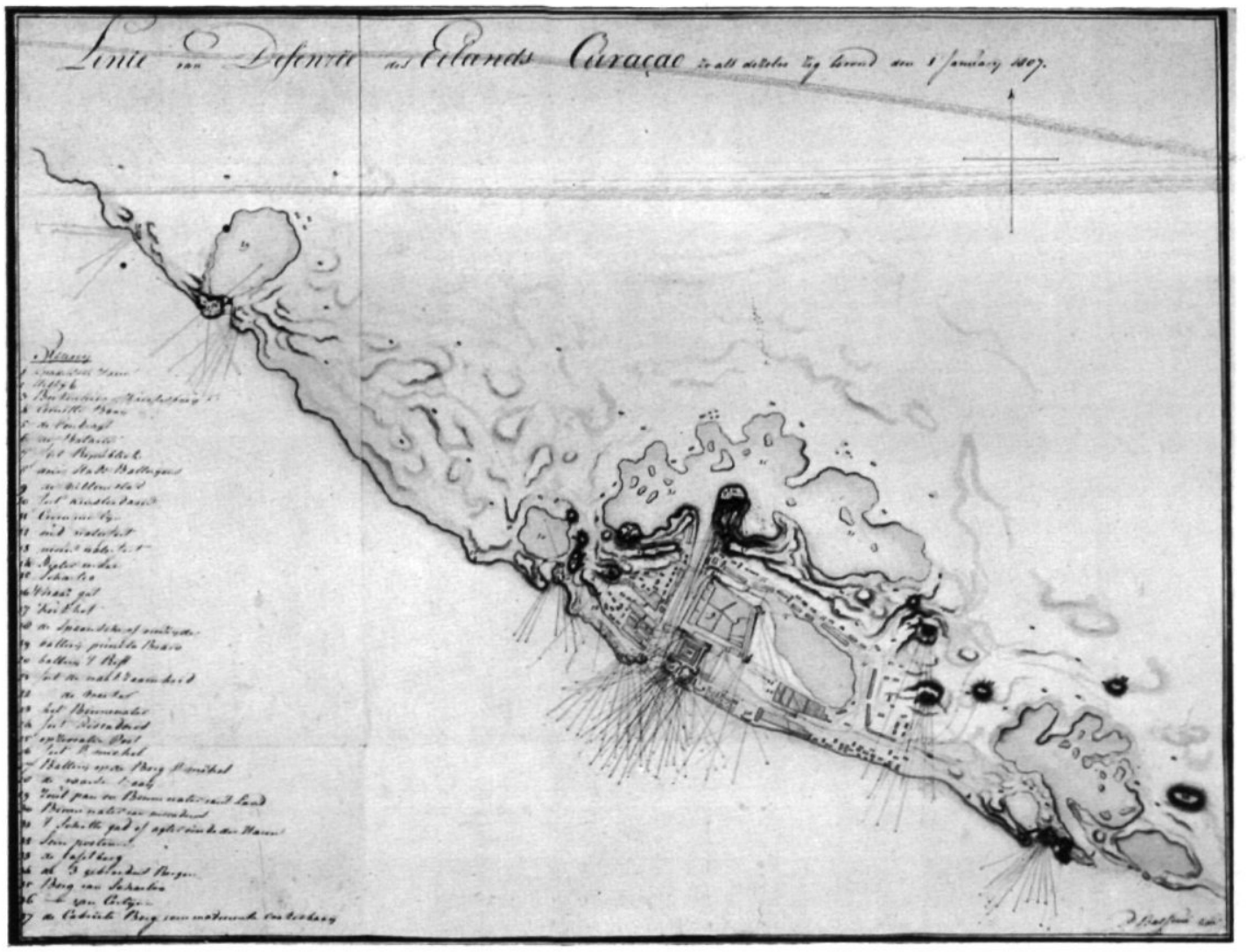

Deze kaart, vermoedelijk geteekend door den luitenant P. Balfour van Burleigh, bevindt zich op het Algemeen rijksarchief te 's-Gravenhage in Changuions memorie, in 1814 aan Koning Willem I overhandigd. Zie blz. 196 noot. 
Hoe is het mogelijk, dat geen der officieren wat meer moed en zelfbeheersching bezat dan Pfeiffer? Waarom is er niets op de schepen gebeurd, toen de uitkijk op de „Kenau Hasselaar” om vijf uur de Engelsche schepen had waargenomen? De Hooge militaire vierschaar spreekt van een samenloop van omstandigheden, waardoor de verrassing is geslaagd; als altijd is dat ook nu het geval geweest, maar voor elk van die omstandigheden, voor zoover van beslissenden aard, is een persoon verantwoordelijk te stellen, die in zijn plicht is tekortgeschoten. Rechtstreeks is Changuion wellicht de minst schuldige. Zijn verregaande zorgeloosheid, zijn in zulke critieke omstandigheden naar-buiten-gaan kan alleen verklaard worden uit misplaatst optimisme omtrent hetgeen ook na de sommatie van 22 December 1806 wel weer niet gebeuren zou, en uit een zekere moedeloosheid over den gang van zaken twee jaar lang. Waarschijnlijk heeft hij er niet eens aan gedacht, om dezen oudejaarsnacht alle officieren op hun post te houden, maar door zijn voorbeeld had Changuion het zedelijk recht tot het geven van dit bevel verbeurd. En de zeeofficieren hebben wel op heel vrijmoedige wijze het voorbeeld van hun hoogsten chef gevolgd. Van ernstige ziekte van den gouverneur, die zijn afwezigheid noodzakelijk maakte, blijkt niets. Hij vond eenvoudig de nieuwjaarsreceptie vervelend, en heeft daaraan willen ontkomen, alsof in oorlogstijd daarvoor niet een ander middel te vinden ware.

Ook de burgerij heeft in den geest van zorgeloosheid gedeeld. De Veer en Hendricus gaven feesten, alsof er geen wolkje aan de lucht was. Pfeiffer had de laatste moeten zijn, om zich ervoor te beklagen, dat op de zoo laat geloste alarmschoten niemand van de burgermacht in het fort verschenen is. Uit de mededeelingen van Schmidt en Plats blijkt, dat op dat uur de weg daarheen al niet meer vrij was. Maar het waren dan toch niet meer dan een twintigtal mannen, onder welke drie officieren, die zij konden meekrijgen naar fort Republiek en de batterij Waakzaamheid.

Voorwaar, een der vele droeve bladzijden uit de geschiedenis is voor ons die, waarop de verrassing van Curaçao op 1 Januari 1807 geschreven staat.

Amsterdam 10 November 1942. 